\title{
OS SENTIDOS DO POPULISMO PENAL: UMA ANÁLISE PARA ALÉM DA CONDENAÇÃO ÉTICA
} THE WAYS OF PENAL POPULISM: AN ANALYSIS BEYOND THE ETHICAL CONDEMNATION

\author{
Marcelo Butelli Ramos ${ }^{1}$ \\ PUC/RS \\ Ricardo Jacobsen Gloeckner ${ }^{2}$ \\ $\mathrm{PUC} / \mathrm{RS}$
}

\begin{abstract}
Resumo
Os autores pretendem, neste artigo, problematizar o entendimento que baseia grande parte das análises contemporâneas que relacionam a noção de populismo penal ao fenômeno da expansão do direito penal: o de que a noção denota uma espécie de anomalia política que deriva do desgaste do modelo democrático representativo e que tende a comprometer a racionalidade garantista dos sistemas jurídico-penais contemporâneos. Para tanto, aos autores realizarão, inicialmente, um levantamento bibliográfico com o propósito de ilustrar o tratamento analítico dispensado à noção no âmbito dos debates criminológico e dogmático penal contemporâneo. Ato contínuo, os autores argumentarão acerca da possibilidade de se realizar uma releitura da noção a partir da abordagem teórica preconizada por Ernesto Laclau. Cotejadas as diferentes perspectivas teóricas, os autores concluirão que a maior parte das críticas ao que se convencionou chamar de populismo penal deriva da assunção de certas pressuposições que substituem a explicação do fenômeno pela sua condenação ética. Finalmente, os autores colocarão em debate duas novas hipóteses: a primeira reclama interpretar o populismo como uma lógica política indispensável nos regimes democráticos; a segunda concerne ao entendimento de que a realidade atualmente retratada pelo termo pode ser mais adequadamente compreendida à luz do conceito de pânico moral.
\end{abstract}

1 Mestre em Ciências Criminais pela Pontifícia Universidade Católica do Rio Grande do Sul (2016). Advogado. E-mail: mbuttelliramos@hotmail.com. Currículo Lattes: http:/ /lattes.cnpq.br/8532081844321742.

2 Pós-doutor em Direito pela Università Federico II, de Nápoles (2016), e Doutor em Direito pela Universidade Federal do Paraná. Professor do Programa de Pós-graduação em Ciências Criminais e Coordenador do Curso de Especialização em Ciências Penais da Pontifícia Universidade Católica do Rio Grande do Sul. E-mail: ricardogloeckner@hotmail.com. Currículo Lattes: http://lattes.cnpq.br/2085174043653648 
Palavras-chave

Populismo Penal. Criminologia. Teoria Política. Pânico Moral. Expansão do Direito Penal.

\begin{abstract}
In this article the authors intend to problematize the relation between penal populism and criminal law expansion. The majority of studies focus on populism like an anomaly derived from the erosion of representative democracy model, with its trend to erode the guarantees rationale of contemporary law systems. To demonstrate this, the authors will proceed to a bibliographic review, with the purpose to illustrate the analytic treatment given to the penal populism notion in the criminological and legal doctrine debate. The authors will also provide arguments for a new form of understanding penal populism through the theoretical approach of categories provided by Ernesto Laclau. Given the differences among the theoretical perspectives, the authors will conclude that the major set of critiques addressed to the so-called penal populism derives from certain assumptions that replace the comprehension of the phenomena by its ethical condemnation. Finally, the authors will put into debate two news hypotheses: the first interprets the populism as a political logic, indispensable to the democratic regimes. The second concerns the assumption that the reality invoked by the penal populism could be fairly comprehended through the moral panic concept.
\end{abstract}

\title{
Keywords
}

Penal populism. Criminology. Political theory. Moral panic. Criminal law expansion.

\section{INTRODUÇÃO}

Não obstante a moratória da prisão constitua fato incontroverso, o sistema jurídico-penal brasileiro segue, impassível, num franco movimento de expansão. Passados mais de 30 anos da retomada do regime democrático no Brasil, os limites impostos à liberdade dos brasieliros constituam sendo discutidos e instituídos a partir do marco jurídico-penal. Diante deste cenário, não parece ser exagero afirmar que a democracia brasileira claramente afeita à adoção da solução penal como forma preferencial de resolução dos conflitos socias - apresenta-se não como momento de ruptura em face de uma ordem autoritária, mas, antes, como uma espécie de continuum formado por práticas e discursos que não deixam olhar para $o$ regime militar como se ele representasse um passado distante, superado. Neste cenário, algo desalentador, novos fatos da vida social são, com frequência, caputrados pela práxis legislativa, que, quando não engendra novos tipos penais, trata de punir com mais intensidade condutas previamente tipificadas. Com efeito, nas últimas décadas, têm sido cada vez 
mais tímidos e pontuais os movimentos institucionais dispostos a reduzir o campo de internveção da tutela jurídico-penal (MATHIESEN, 2003, p. 59).

Pressionados por novas e crescentes demandas sociais por punição, o Poder Legislativo parece ter se rendido ao entendimento dessa corrente do pensamento que preconiza a inculcação da pena como um dogma, como um instrumento suficiente (e também eficiente) de controle e apaziguamento da conflitividade social (YOUNG, 2002, p. 170). À toda evidência, encontra-se em curso, na atualidade, o retorno gradual da política criminal brasileira à dantesca matriz ideológica do positivismo criminológico clássico, onde o que importa, apenas, é a nulificação dos potenciais riscos encarnados na figura do desviante, alguém que está "para além da redenção" (KARAM, 1996, p. 79).

Essa dilatação do campo de intervenção do Direito Penal, contudo, parece operar segundo os ditames de uma racionalidade latente, subepidérmica. Não por fatalidade ou coincidência que a prisão, "essa detestável solução, de que não se pode abrir mão” (Foucault, 2010, p. 218), passa a desempenhar, na atual quadra da história, certas funções que lhe dão novo significado, permitindo-o, assim, escamotear o velho sob a aparência do novo (BUTLER, 1997). Lembremos, a propósito disso e consoante os ensinamentos de Michel Foucault, que é através da "inflação legal, da inflação dos códigos jurídicos legais", que são aperfeiçoados "os mecanismos de controle social", de modo a adequá-los à constante metamorfose das relações sociais (FOUCAULT, 2008, p. 11).

Ocorre que essa vontade de ordem, frustrada diária e sistematicamente pela dinâmica fluida e volátil das relações estabelecidas em uma modernidade líquida - onde, conforme antigo vaticínio aduzido por Karl Marx "tudo que é sólido desmancha no ar" - tem servido como uma espécie de combustível ideológico, que aumenta a temperatura emotiva do debate sobre a questão criminal e que culmina, como regra, na edição de um novo e miraculoso recurso jurídico-normativo que, vindo ao mundo sob o pretexto de reestabelecer a ordem e a autoridade das instituições públicas, promete à cidadania um futuro menos incerto e ameaçador (BAUMAN, 2007, p. 10). 
De efeito, a crença que hoje se difunde é a de que as ações do sistema de justiça criminal deveriam se orientar no sentido da concepção de uma estratégia global de gerenciamento dos medos e das expectativas sociais insufladas, em larga medida, pelos meios de comunicação de massa, que, autoinvestidos na qualidade porta-vozes da cidadania, por sua vez, reclamam do Estado, respostas cada vez mais rápidas, duras e pragmáticas em relação ao enfrentamento da violência urbana (MARTINS, 2013, pp. 3334; SILVA SÁNCHEZ, 2001, p. 74).

É justamente esse cenário que serve como pano de fundo para a discussão daquele fenômeno que se convencionou chamar de "expansão do direito penal", assim compreendido o movimento político-criminal caracterizado: (i) pela relativização das garantias penais básicas oriundas do Direito Penal ilustrado, tais como: a intervenção mínima do direito penal e a proporcionalidade das penas; (ii) pela descoberta de novos bens e interesses jurídicos merecedores da tutela penal (bens estes supostamente revelados ao legislador graças à intensificação do processo de complexibilização das relações sociais)"; (iii) pela flexibilização das "regras de imputação jurídico-criminais"; (iv) pela construção de uma legislação penal carente de orientação dogmática e baseada, no limite, em demandas sociais conjecturais, episódicas e superficiais; (v) pela difusão e inculcação da crença de que a legislação penal representa uma solução viável para a resolução de uma ampla variedade de problemas sociais e, finalmente; (vi) pelo implemento de reformas penais inspiradas, no limite, pela ideologia do movimento de lei e ordem e marcadamente simbólicas, isto é, desprovidas

3 Interessante observar que para Silva Sánchez, o movimento de expansão da normatividade jurídico-penal não representa, em si, uma manifestação da perversidade Estatal (SILVA SÁNCHEZ, 2001, p. 113). Abstraindo do maniqueísmo que costuma permear às críticas ao movimento de expansão do Direito Penal, o autor lembra ser possível sustentar, sob o ponto de vista dogmático, uma expansão "orientada" ou "razoável" do Direito Penal, com o intuito de proteger - por outros meios que não apenas pela pena privativa de liberdade - expectativas sociais específicas e reconhecidamente legítimas, tais como: a vida, a saúde, a liberdade e o patrimônio; expectativas cujo abandono daria lugar a reações disfuncionais. Daí porque, segundo o entendimento do autor, não resultaria incoerente defender a necessidade de um Direito Penal funcional e autorrestritivo (SILVA SÁNCHEZ, 2001, p. 114). 
de qualquer compromisso efetivo com o desenvolvimento do sistema jurídico-penal com vistas ao aprimoramento das funções de proteção e garantia comumente atribuídas à pena (SILVA SÁNCHEZ, 2001, p. 20).

Neste último sentido, ao longo dos últimos anos ganharam Várias foram as propostas teóricas de interpretação das causas que determinaram a ocorrência do fenômeno no âmbito da legislação criminal. Com efeito, alguns teóricos optaram pela utilização de abordagens macrossociológicas, tal como aquela propugnada por Anthony Giddens (1991), a fim de problematizar as relações estabelecidas entre o processo de refinamento teórico da noção de risco, a emergência de políticas de enceramento de natureza preventiva e, finalmente, o desenvolvimento práticas e discursos autoritários e/ou calculistas/ atuariais por parte dos órgãos e agentes integrantes do sistema de justiça criminal (SIMON, 2007, p. 10; YOUNG, 2002, p. 108; GLOECKNER, 2009, p. 169); outros autores, no entanto, enxergaram neste contexto a oportunidade de questionar não apenas o papel desempenhado pelos atores do processo secundário de criminalização, mas, também, a comportamento dos próprios legisladores, protagonistas, estes, do processo primário de criminalização ${ }^{4}$ (PAIVA, 2009, p. 13).

Notoriedade análises cujo intuito primário consiste em relacionar o fenômeno àquilo que se convencionou chamar de populismo penal. Não obstante, tal expressão, que tudo parece explicar, carece, ela própria, de uma definição precisa, sob o ponto de vista analítico. Tal imprecisão - como poderemos atestar ao longo deste trabalho - faz com que a crítica criminológica, na tentativa de explicar o fenômeno, caia insistentemente na armadilha de reduzi-lo a um conjunto de descrições pejorativas, deixando, assim, de investigar as especificidades dos discursos que guindam o povo à

\footnotetext{
${ }^{4}$ Em razão do uso desta expressão, cabe a realização do seguinte esclarecimento: enquanto que o processo primário de criminalização alude ao processo legislativo incumbido da constituição das normas de direito penal; o processo secundário de criminalização diz respeito, no limite, a atuação das instâncias oficiais incumbidas da atividade de persecução penal (v.g. Polícias, Magistratura, Ministério Público, Departamentos Penitenciários etc.), isto é, da aplicação das normas produzidas pelo Congresso Nacional.
} 
condição de referente empírico de legitimação (democrática) do processo primário de criminalização.

\section{OS SENTIDOS DO POPULISMO PENAL}

No âmbito dos discursos criminológicos de orientação crítica, é possível sondar a existência de alguns estudos que, com certo rigor analítico, esboçam a pretensão de discorrer com alguma precisão terminológica acerca da temática do populismo punitivo.

O primeiro dos autores a ser enfatizado neste inventário conceitual é - como não poderia deixar de ser - o criminólogo britânico Anthony Bottoms. Apontado por Elena Larrauri e por John Pratt como o artífice da expressão populismo penal (LARRAURI, 2007, p. 1; PRATT, 2007, p. 2), Bottoms foi o primeiro teórico a preconizar a possibilidade de se estabelecer um ponto analítico de convergência entre o fenômeno populista e o fenômeno de expansão da normatividade jurídico-penal. Descrito por Bottoms como a main movement of thought (BOTTOMS, 1995, p. 39), o populismo punitivo, ou, para sermos mais precisos, a punitividade populista ("populist punitiveness"), indicaria, basicamente, um traço característico do comportamento daqueles agentes políticos (politicians) que almejam conquistar algum tipo de vantagem eleitoral por intermédio da produção ou indução de reformas legislativas inspiradas em teses como as seguintes: (i) o incremento das sanções de caráter penal produz, imediata e automaticamente, uma redução significativa nos indicadores da criminalidade (prevenção social negativa); (ii) a pena, per se, reforça determinados consensos morais essenciais para a manutenção da vida em sociedade (prevenção social positiva). Apresentado pelo autor como uma espécie de estratagema político escuso voltado unicamente à manipulação 
da opinião pública, o populismo punitivo destacar-se-ia, nesse contexto, como uma manifestação concreta da retórica manejada por políticos profissionais que procuram realizar, de forma cínica e oportunista, um conjunto de reformas penais com o intuito de ganhar votos ao invés de reduzir, de forma efetiva, a conflitividade social (BOTTOMS, 1995, p. 39).

Para Elena Larrauri, o populismo penal ou punitivo apresenta-se como o mais destacado projeto político-criminal da atualidade. Por se alimentar de um contexto social alucinado, melindrado pelo pânico moral que resulta da manipulação das imagens da violência urbana pelos meios de comunicação de massa (COHEN, 2011, p. xx), essa faceta moderna do discurso criminalizador estaria a ilustrar um movimento institucional extremamente hábil na formatação de leis penais dotadas de uma eficácia puramente simbólica, leis que funcionam, no limite, como uma espécie de álibi político cujo propósito maior é escusar o Estado e seus agentes políticos, sobretudo o seu corpo parlamentar, do oferecimento de soluções mais estruturais e menos violentas para questões relacionadas à temática da conflitividade social (LARRAURI, 2007, pp. 7-8).

Jonathan Simon (2007), por seu turno, descreve o populismo punitivo como uma tendência liberal ultraconservadora cujo mote é a superação definitiva do paradigma do previdenciarismo penal. No entendimento do autor, a proposta populista sugere, pois, o completo abandono do ideal (re)socializador como lastro ético estruturante das ações do sistema de justiça criminal: em seu lugar, aconselham os populistas, devese adotar uma nova perspectiva relativamente às finalidades do controle jurídico-penal. Para Simon, o populismo dito punitivo expressa, sob o ponto de vista conceitual, uma necessidade (política) de se aderir a outro sistema mais simples e eficiente de regras e princípios jurídicos: um sistema que permitiria às sociedades assoladas pelo medo da criminalidade viver sem ter que se preocupar com a superação das dificuldades inatas às tentativas de concretização de uma promessa (humanitária) cuja consecução depende, necessariamente, de um esforço comunitário que transcende a lógica liberal que inculca a prevalência dos direitos e interesses individuais (SIMON, 2007, pp. 150-151). Para Simon, o populismo penal representa um dos principais elementos constitutivos da retórica política que informa as 
práticas de denominadas pelo autor de "governo através do crime" e se notabiliza, no âmbito do cenário político-criminal contemporâneo, pela crueza das respostas que oferece à questão criminal.

De acordo com Simon, os discursos punitivos de corte populista, preferidos entre os atores políticos de ambos os lados do espectro políticoideológico, representam, no limite, uma tentativa de reinventar a legitimidade democrática da já fustigada e combalida figura do político profissional; neste sentido, o próprio conceito de populismo punitivo estaria a representar, para além de uma tendência política (de endurecimento das leis penais e investimento nas instâncias oficiais de controle da criminalidade) que responde a uma necessidade igualmente política (de governar através do fomento do sentimento de medo do crime), uma racionalidade legislativa que pressupõe, a um só tempo, um tipo ideal de legislador e um tipo ideal de diploma legislativo. No que concerne legislador ideal, o populismo punitivo (como uma espécie de ideologia) exige dos políticos profissionais a adoção de uma "ética" particular relativamente ao seu agir legislativo. Neste sentido, para que possa ser considerado um "bom legislador" - assim compreendido o político que bem representaria os genuínos interesses do povo - o político (populista) deve agir (ou ao menos aparentar agir), frente as questões criminais, com o intuito de defender os interesses das vítimas (reais ou potenciais) da criminalidade através da ampliação dos poderes atribuídos aos órgãos estatais incumbidos da atividade de persecução criminal. Qualquer outra atuação que escape a tais finalidades acaba sendo interpretada como uma espécie erro legislativo ${ }^{5}$. Já no

\footnotetext{
$5 \mathrm{O}$ argumento apresentado por Simon de modo algum pode ser considerado alheio à realidade político-criminal brasileira. Lembremo-nos, com efeito, do exemplo doméstico, pertinentemente problematizado por PAIVA (2009), que alude ao imbróglio político e jurídico decorrente da promulgação da Lei Federal n. 11.464/07, diploma normativo que alterou a Lei dos Crimes Hediondos (8.072/90) com o intuito de tornar mais severas as regras para a progressão de regime prisional. Conforme observa Paiva, a urgência estabelecida em torno da aprovação do texto do Projeto de Lei que deu ensejo à Lei Federal n. 11.464/07 fez com que os "bons legisladores" olvidassem da presença de outro artigo no texto do PL que restituída aos condenados em processo criminal o direito de apelar em liberdade. Duas semanas após a promulgação da Lei o "equívoco" foi finalmente reconhecido e o mal-estar logo estabelecido. Interpelados pelos grandes veículos de
} 
que diz respeito ao tipo ideal de diploma legislativo pressuposto pela racionalidade legislativa populista, Simon destaca que as leis penais (ditas populistas) falam, através do agravamento muitas vezes extraordinário das sanções, da necessidade (utilitária, no limite) de uma relativização dos direitos humanos de acusados e condenados como estratégia de controle dos "sempre" elevados índices de criminalidade, tudo a pretexto de realização da vontade popular. Nesse sentido, as leis penais são percebidas como instrumentos preferências no controle da violência cujo propósito consiste na pavimentação do caminho que guiará o criminoso em direção a um espaço de custódia incumbido da função de separar fisicamente da comunidade de não-desviantes aqueles sujeitos cuja propensão para o cometimento de crimes gera riscos intoleráveis para toda a sociedade. Interessante observar que é neste contexto, pois, que se verifica o advento, não apenas nos EUA, mas também nos países que, à semelhança do Brasil, importaram a política estadunidense da guerra contra o crime, das waste management prisons, tipos de instituições notabilizadas, sobretudo nos EUA, tanto pelas práticas extremas de confinamento adotadas, como pela violação sistemática de direitos humanos (SIMON, 2007, p. 154).

Nessa mesma linha compreensiva segue o criminólogo argentino Máximo Sozzo, para quem o populismo punitivo ilustra um "novo jeito de fazer política", uma estratégia fundamental de controle do crime que propugna, basicamente, o endurecimento contínuo das políticas penitenciárias como forma de superar o fracasso do ideal liberal ressocializador. Embora reconheça a dificuldade inerente à tentativa de se estabelecer contornos efetivamente objetivos para o termo, o autor arrisca dizer que o populismo penal poderia ser mais claramente compreendido caso fosse retratado como uma espécie bastante peculiar de política criminal que invoca, enquanto fundamento de legitimidade, as aspirações securitárias manifestadas por um povo que assume, para si, a identidade de vítima da criminalidade (SOZZO, 2009, p. 42).

comunicação, vários dos parlamenteres responsáveis pela aprovação do projeto de lei argumentaram, em tom de "mea culpa", que o "erro" seria corrigido. Oito projetos de lei foram imediatamente apresentados na expectativa de suprimir do texto legal o artigo controvertido. Nenhum deles, no entanto, foi aprovado (PAIVA, 2009, p. 12). 
O criminólogo John Pratt, autor da obra Penal populism (2007), não destoa dos demais autores ao referir que o populismo penal representa uma das mais significativas mudanças "na configuração do poder penal na sociedade moderna" (PRATT, 2007, p. 21). Reconhecendo o uso indiscriminado da expressão como uma tentativa - um tanto precária e desencontrada - de explicitar as razões determinantes das mudanças estruturais ocorridas no campo da penalidade a partir da década de setenta (identificada, pelo autor, como momento que marca a derrocada (fiscal) do modelo de Estado baseado na promoção do ideal do bem-estar social e o declínio do seu projeto ressocializador), o autor afirma ser possível captar a especificidade (essência) do fenômeno a partir da enumeração das suas "principais" características (PRATT, 2007, p. 53).

Para Pratt, a dimensão populista do fenômeno punitivo se expressa pelo fato de que há, nas sociedades modernas, um descontentamento popular generalizado relativamente ao funcionamento do sistema de justiça criminal; tal descontentamento traduzir-se-á - a exemplo do que ocorre no canário nacional - numa série de discursos que, fazendo confluir os significantes impunidade, medo e violência, tem reivindicado a formação de uma fronteira interna no espaço social que separa, de um lado, o povo, constituído, sobretudo, pelas vítimas da violência urbana, e, de outro, uma identidade política marginalizada que, de acordo com a crença que se encontra hoje difundida, tende a se beneficiar, direta ou indiretamente, com a complacência de um direito penal garantista. Eis, a propósito, a condição que Margaret Canovan ${ }^{6}$ considera fundamental para se determinar o caráter populista de um determinado fenômeno social: o apelo ao povo como protagonista de uma ruptura antielitista em face de uma determinada ordem política ou jurídica (CANOVAN, 1981, p. 9).

Para o criminólogo, o populismo punitivo - enquanto fenômeno social - denota uma cosmovisão contemporânea sobre a penalidade que trata de refutar, veementemente, o projeto político-criminal preconizado

\footnotetext{
${ }^{6}$ É digno de nota, no ponto, o fato de que a análise referendada por Pratt sobre a "punitividade populista" inspira-se, claramente, no arcabouço conceitual preconizado pela politóloga inglesa em seus textos sobre a temática do populismo.
} 
pela tradição liberal do período do pós-guerra. Essa recusa perpassa, escreve Pratt, pela assunção de um conjunto bastante específico de princípios orientadores de novas estratégias de prevenção e enfrentamento da criminalidade:

(...) deveria haver muitas prisões ao invés de poucas; a punição deveria ser transformada em um espetáculo público ao invés de ser considerada uma conquista da racionalidade burocrática alcançada longe dos olhos da opinião pública; o conhecimento popular deveria ser priorizado em face do conhecimento oficial dos especialistas sobre o sistema de justiça criminal. (PRATTT, 2007, p. 35)

Outro traço característico do populismo penal consistiria na disseminação da tese sobre a prevalência dos direitos comunitários de acesso à justiça e segurança sobre os direitos de natureza individual. $\mathrm{Na}$ esteira do léxico punitivo-populista, direitos e garantias individuais representam, inexoravelmente, instrumentos jurídicos ultrapassados cujo manejo tem assegurado, injustamente, a liberdade daqueles que não podem viver em sociedade por serem simplesmente incapazes de compreender e assumir os seus valores mais elementares (PRATT, 2007, p. 12). Outra particularidade empiricamente observável em contextos ditos populistas anota Pratt - diz respeito ao estreitamento dos laços existentes entre as instâncias do law enforcement e todas aquelas organizações oriundas da sociedade civil ("law and order groups") que avocam para si o poder falar em nome das vítimas (com ou mesmo sem a sua permissão) (p. ex. associações de pais contra a violência, movimentos em prol da ampliação da pena para os crimes praticados contra animais, associações de vítimas de abuso sexual, etc.). A consolidação desse elo, conforme sugere o autor, tem como implicação direta o enfraquecimento das ligações do Estado com as suas próprias agências burocráticas de aconselhamento (PRATT, 2007, p. 35). Deste movimento de sobreposição de instâncias resulta a constatação de que, em cenários tipicamente populistas, o ideário popular punitivo tende a acessar e mobilizar, com maior facilidade, os canais institucionais responsáveis pela elaboração de reformas político-criminais, de tal forma 
que, não raras vezes, expectativas setorizadas transmutam-se em amplas políticas públicas de encarceramento (PRATT, 2007, p. 35). Consequentemente, ao exaltar autenticidade do popular commonsense em detrimento da frieza e da abstração dos indicadores estatísticos produzidos pelos experts ${ }^{7}$, os discursos populistas, de corte punitivista, seriam dotados de uma natureza anti-intelectual, posto que impulsionados por uma força política guiada tanto mais pela emoção - canalizada, sobretudo, pelos discursos de vitimização - que pela razão (PRATT, 2007, p. 17; p. 92).

David Garland, por sua vez, encara o populismo como uma espécie peculiar de discurso político que nasce em resposta à crise do Estado de Bem-Estar Social e que demonstra ter, basicamente, um único objetivo: legitimar, no plano dos debates legislativos que versam sobre a questão criminal, uma razão discursiva baseada naquilo que Alessandro Baratta chamou de "everyday theories" (Baratta, 2002, p. 42), assim compreendidos os juízos opinativos proferidos pelos "homens da rua". Para o autor, o signo distintivo que marca e define o populismo, enquanto discurso político, diz respeito à sua notável capacidade para democratizar o acesso ao conteúdo das reformas legais em matéria penal, retirando assim dos "experts" (p.ex. juristas, sociólogos, criminólogos, administradores penitenciários etc.) a palavra final sobre o funcionamento e sobre as finalidades a serem perseguidas pelo sistema de justiça criminal (GARLAND, 2008, p. 279).

Outra abordagem teórica que avança sobre a problematização do conceito diz respeito àquela levada a efeito pelo magistrado francês Denis Salas, autor de "La Volonté de punir: essai sur le populisme penal" (2010). Segundo o autor, o populismo penal emerge como um discurso político que resulta (enquanto sintoma) da inoculação de duas patologias políticas no âmbito dos regimes democráticos contemporâneos: a patologia da acusação e a patologia da representação. No primeiro caso, a (dis)funcionalidade do discurso populista propõe a ressignificação do ato de punir. A negatividade inerente ao ato é obnubilada, em grande parte, por uma nova conotação

\footnotetext{
7 Tal característica adquire uma incontestável importância no âmbito das análises conduzidas por Pratt, que, em determinado momento de sua obra, chega a sugerir a "desestaticalização" (destatisticalization) das discussões sobre crime como principal implicação dos discursos populistas (PRATT, 2007, p. 89).
} 
prenhe de positividade: a punição dá-se não tanto em prejuízo dos criminosos, mas sim em favor das vítimas. Assim, ressignificado, o poder de punir é radicalizado, a sociedade, carente de segurança, passa a exigir mais acusações, mais julgamentos e mais condenações. Frente a esse contexto, os legisladores passam a operar com o intuito de superar aquilo que representa a segunda patologia identificada pelo autor: a crise de representatividade política, que, agravada, passa a representar a própria crise de legitimidade da forma-partido e do parlamento, enquanto instituição. Diante desse cenário, não interessaria mais ao parlamento, portanto, o controle e a racionalização - sob o prisma garantista - dos influxos incriminadores oriundos da sociedade que clama por punição, uma vez que, pressionado, passa a compreender que "[t]oda a hesitação é um indício de fraqueza. Toda prudência, um indício de cumplicidade" (SALAS, 2010, p. 14).

Para Denis Salas, o populismo penal explicita assim uma dinâmica relacional a partir da qual o Estado, através das suas agências de controle penal, passa a funcionar como uma espécie de caixa de ressonância cujo propósito é dar vazão a certas pulsões que emanam de uma sociedade colocada em permanente estado de excitação por um cerrado e incessante bombardeio midiático, de modo a conformá-la a uma determinada racionalidade burocrática.

Fechando o circuito de autores estrangeiros, seria o caso de se fazer alusão ao entendimento de Carlos Alberto Elbert. Referendado análise sob muitos aspectos similar àquelas realizadas por Pratt e Simon, Elbert asseverará que o populismo penal - sendo a expressão mais bem-acabada da ideologia punitiva contemporânea - poderia ser facilmente ser compreendido como uma:

(...) atitude radicalmente pragmática ante os problemas político-criminais, os quais são concebidos como fáceis de resolver, mediante uma rígida vontade repressiva. Esses ímpetos enfurecidos afastam-se dos princípios constitucionais interpretando as garantias processuais como "concessões", para que os delinquentes obtenham impunidade. (ELBERT, 2011, p. 62) 
Seguindo em sua leitura, o Elbert argumenta que os ideólogos do populismo punitivo, a partir do manejo de um discurso "errático, contraditório e antidemocrático" (ELBERT, 2011, p. 63), contribuíram sobremaneira para a consolidação do atual estado de coisas da política criminal ocidental, contexto a partir do qual as "grandes lições dos teóricos especialistas" foram simplesmente sacrificadas em prol da adoção de uma razão comunicativa mais rápida, objetiva e simplificada, entoada, fundamentalmente, por "grandes formadores de opinião", próceres de um processo de "estupidização global" (ELBERT, 2011, p. 63). Todo esse cenário, denota, para o autor, a consolidação do populismo penal como o modelo hegemônico de controle social nas sociedades ocidentais contemporâneas, um modelo que se ergue, conclui, dos destroços legados pelo histórico fracasso político-cultural do discurso penal liberal de corte garantista.

No Brasil, Luiz Flávio Gomes assenta - em trabalho dedicado à concepção de uma teoria geral sobre o populismo punitivo - mediante a formulação de uma crítica "marginal" às teorias criminológicas sobre o populismo penal, que o fenômeno populista, entendido à luz das especificidades da realidade periférica latino-americana, haveria de ser compreendido não como um novo paradigma punitivo que se contrapõe ao projeto ressocializador welfarista, mas, antes, como uma ideologia conservadora desenvolvida, unicamente, com o propósito de servir aos interesses dos grandes veículos de informação e das instâncias políticopartidárias em sua pretensão de manipulação das massas a partir da exortação de um "velho e desgastado modelo punitivista repressivo" (GOMES, 2013, p. 24). No âmbito da análise referendada pelo autor, o populismo penal afirma-se, sob o ponto de vista conceitual, como um fenômeno político-criminal polivalente que, para além de ser expressão de uma ideologia punitiva "hiperpunitivista", pode ainda ser representado como traço característico das sociedades contemporâneas, onde vicejam discursos punitivos "irracionais, emotivos e desproporcionais" (GOMES,

\footnotetext{
8 Termo utilizado pelo autor procura designar um cenário legislativo caracterizado, fundamentalmente, pela profusão indiscriminada de leis penais (GOMES, 2013, p. 21).
} 
2013, p. 19). Embora reconheça a porosidade semântica do termo, Gomes afirma ser possível estruturar uma espécie de "framework" cuja aplicação permitiria identificar, no âmbito das estratégias político-criminais, a presença daquilo que ele próprio denomina como "populismo punitivo midiático". Segundo o autor, o populismo punitivo midiático teria lugar quando do atendimento de três condições específicas: (i) transubstanciação do modelo democrático representativo numa democracia de opinião ${ }^{10}$; (ii) constituição de uma legitimidade popular "desde baixo" em prol do sistema de justiça criminal; (iii) instrumentalização eleitoreira do direito penal. $\mathrm{O}$ autor avança, contudo, em seu projeto de conceituação do fenômeno. Gomes termina inovando (em comparação às demais análises que o precedem neste estudo) na medida em que afirma, de forma peremptória, ser possível identificar, objetivamente, o ponto que (de)marca o desencontro entre o populismo político e o populismo penal: enquanto que a raison d'être do populismo político consiste no atendimento das "reivindicações diretas da população carente", o mote do populismo penal verifica-se - "visto que este não se origina de puras demandas da população" - na ambição política de instrumentalização da vontade das massas (GOMES, 2013, p. 33). Neste sentido, escreve:

Por meio de eficientes técnicas de manipulação (é nisso que consiste o populismo penal), cria-se ou amplia-se a sensação de insegurança, o sentimento de medo (em síntese, a realidade), explora-se a reação emotiva ao delito, para se alcançar consenso ou apoio popular para a expansão do poder punitivo (mais presídios, mais policiais, mais vigilância

\footnotetext{
${ }^{9} \mathrm{O}$ autor não apenas ambiciona delimitar conceitualmente o fenômeno populista, mas, indo além, pretende, desde logo, aperfeiçoá-lo, destacando, destarte, aquela especificidade que, desde o seu ponto de vista, caracterizaria o populismo penal contemporâneo: o protagonismo e a ascendência dos grandes veículos de comunicação sobre os processos de construção e sedimentação de um imaginário popular punitivo (GOMES, 2013, p. 62).

${ }^{10}$ Para o autor, o conceito de "democracia de opinião", afirmado em oposição ao conceito de democracia representativa, visa retratar contextos políticos nos quais a "opinião pública" é constituída, preponderantemente, nos editoriais dos grandes veículos informação e não propriamente nos espaços públicos de discussão (GOMES, 2013, p. 60).
} 
de toda população, mais poder à polícia, mais controle etc.). (GOMES, 2013, p. 33)

Nessa mesma linha compreensiva segue Luís Wanderley Gazoto, que buscou compreender, em seminal tese de doutoramento publicada junto ao Departamento de Sociologia da Universidade de Brasília - UnB, as razões que determinaram a consolidação de uma tendência de recrudescimento da legislação penal no Brasil nas últimas décadas. Ao longo de sua tese, o autor afirma, em termos conceituais, que o populismo penal designa um estilo de fazer política que se baseia em um discurso ardiloso pronunciado desde os parlamentos, que é retroalimentado pelas mídias de massa e cujo desiderato consiste na manipulação do eleitorado através da concepção de "ações governamentais irracionais, puramente emotivas, de apelo popular - muitas vezes falaciosas - outras tantas maliciosas, as quais supostamente pretendem atender à consciência coletiva" (GAZOTO, 2010, 69).

Curioso notar que essa predisposição analítica para encarar o populismo como um conceito fechado, transparente e operativo, desborda do campo das análises criminológicas a ponto de ser compartilhada por autores do campo da dogmática jurídico-penal. Exemplo disso é a forma como o penalista espanhol José Luis Díez Ripollés enfrenta a temática da expansão do direito penal em seu "La racionalidad de las leyes penales" (2003). Ao analisar a forma como autores da dogmática jurídico-penal concebem a temática do populismo, o autor conclui que, o fenômeno é apresentado, nessas análises, tourt court, como uma espécie de racionalidade política de feição institucional que, em resposta à crescente crise de legitimidade dos modelos de representação política indireta, preconiza a necessidade de criação de diplomas normativos cujo objetivo primeiro consiste em demonstrar a sensibilidade dos políticos profissionais para as demandas e anseios que emanam dos grupos populares. Para o jurista espanhol, o populismo, como estratégia discursiva, ilustra um movimento político fagocitário a partir do qual a forma democrática representativa passa a incorporar, à sua estrutura deliberativa, um conjunto de práticas típicas de outra organização política cuja legitimidade das 
decisões é identificada mais facilmente, quase intuitivamente: o modelo democrático participativo (DÍEZ RIPOLLÉS, 2003, p. 60). Embora discorde da forma simplista como a questão do populismo é colocada no interior do debate político-criminal contemporâneo ${ }^{11}$, o autor reconhece que o fenômeno vem sendo retratado, tanto por representantes da cultura jurídica como por membros da comunidade científica, como uma espécie de anomalia política que tende a comprometer, em última instância, a racionalidade garantista dos sistemas jurídico-penais contemporâneos. Uma das principais críticas formuladas em detrimento do fenômeno, neste sentido, repousa sobre o argumento que sustenta que a existência de contextos populistas pressupõe, invariavelmente, a verificação de cenários nos quais as opiniões sociais sobre temas político-criminais estão total ou profundamente condicionadas ao atendimento de um conjunto de necessidades psicológicas bastante questionáveis.

Neste sentido, na medida em que a tutela penal é invocada, popularmente, como instrumento que visa o restabelecimento de um equilíbrio emocional abalado pelo medo da criminalidade violenta, toda manifestação popular no interior do debate político-criminal seria dotada, invariavelmente, de um forte componente de irracionalidade (DIEZ RIPOLLÉS, 2003, p. 192).

\section{POPULISMO COMO ANOMALIA POLÍTICA: AQUILO QUE SUBJAZ A CONDENAÇÃO ÉTICA DO FENÔMENO}

A catalogação das definições constantes do tópico anterior permitiu constatar que, longe de formarem um bloco conceitual estrito e coeso, as abordagens criminológicas sobre o populismo representam uma verdadeira

\footnotetext{
${ }^{11}$ De acordo com Díez Ripollés, o questionamento sistemático da participação popular nos processos de deliberação sobre matérias de política criminal, longe de representar a possibilidade de se salvaguardar a racionalidade (técnica) do conteúdo das leis penais, termina colocando em questão "o próprio modelo de sociedade democrática e pluralista com o qual nos identificamos e por cuja preservação nos empenhamos" (DIEZ RIPOLLÉS, 2003, p. 60).
} 
formação discursiva, segundo o critério da regularidade em dispersãa ${ }^{12}$. Tal suposição decorre da possibilidade de identificarmos - a partir da análise dos conceitos formulados pelos autores visitados - certos traços compartilhados que revelam a existência de uma narrativa constituída em torno daquilo Wittgenstein chamou de semelhanças de familia ${ }^{13}$. Os traços de similitude identificados em cada uma das abordagens analisadas revelam, em linhas gerais, que o entendimento que vigora entre a maior parte dos criminólogos consultados é o de que o populismo punitivo traduz, fundamentalmente, uma espécie de estratégia político-eleitoral destinada ao gerenciamento das expectativas sociais sobre a questão criminal, cujo escopo consiste na indução de reformas legislativas pontuais sempre em resposta a um conjunto igualmente pontual de demandas sociais episódicas. Embora

12 Inspirados na "Arqueologia do Saber" de Michel Foucault, Laclau e Mouffe sustentam que a "regularidade em dispersão" representa o mais elementar princípio de constituição de uma formação discursiva. Para os autores, uma formação discursiva "não é unificada pela coerência lógica de seus elementos, nem por um sujeito transcendental apriorístico", afinal, essa interpretação pressupõe a existência de certos sentidos dotados de uma realidade extradiscursiva que seriam, por essa razão, imunes às articulações e deslocamentos de sentido produzidos, com efeito, no interior de um discurso. (LACLAU; MOUFFE, 2015, p. 178). Para Laclau e Mouffe, uma formação discursiva deve, antes, ser representada como uma "totalidade constituída através da articulação de elementos diferenciais" (LACLAU; MOUFFE, 2015, p. 178). Assim, o "sentido" do discurso emerge sempre contextualmente a partir da análise das relações estabelecidas entre os elementos teóricos e empíricos que o constituem. Importante salientar, contudo, que a compreensão de Laclau e Mouffe acerca de uma "formação discursiva" se distancia daquela enunciada originalmente por Foucault na medida em que os autores reputam inconsistente a distinção entre práticas discursivas e não-discursivas sustentada pelo filósofo francês (LACLAU; MOUFFE, 2015, p, 181).

13 Ainda que tentemos elaborar precisas definições analíticas que sejam dotadas de um conteúdo normativo transcendental, seremos invariavelmente confrontados com contextos que excepcionarão o sentido idealizado e plasmado em uma formulação pura e logicamente bem estruturada. Neste sentido, muito mais útil que a formulação de sentidos últimos acerca do populismo punitivo, é a verificação, a partir de uma análise em sentido estrito dos discursos que mobilizam o termo, daquilo que Wittgenstein chamou de "semelhanças de família", assim compreendidos os traços sobrepostos, reiterados e/ou compartilhados por um número considerável de discursos que, embora relacionados, não possuem uma identidade "a priori" (WITTGENSTEIN, 2014, p. 51, \$\$65 e 67). 
sejam vários os autores e enfoques atribuídos ao tema, o tratamento dispensado à questão geralmente é o mesmo: o fenômeno populista é apresentado, "tout court", como uma espécie de degeneração da racionalidade legislativa pressuposta pelo modelo democrático representativo. Sucede, no entanto, que as análises criminológicas anteriormente elencadas têm perscrutado o fenômeno de maneira ad hoc, a partir de uma argumentação pautada por descrições essencialmente alusivas, motivo pelo qual resta frustrada qualquer tentativa de precisar o tipo de lógica política que subjaz o fenômeno (LACLAU, 1978, p. 149). Em outras palavras: é como se a literatura criminológica relativa ao tema optasse quando defrontada com a necessidade de oferecer uma explicação mais estrita em relação ao fenômeno - por aderir a um senso comum inculcado que esconde, de forma conveniente e até certo ponto convincente, certo déficit na reflexão acerca dos pressupostos subjacentes às estratégias de mobilização de identidades políticas $\operatorname{coletivas}^{14}$ - forjadas a partir de movimentos de identificação e diferenciação simbólica - no interior dos discursos parlamentares. Ademais disso, foi possível constatar, mediante a realização de um breve inventário conceitual, que cada uma das abordagens anteriormente elencadas compartilha, em maior ou menor medida, do entendimento de que a experiência populista consubstancia um excesso de sentido que desafia a racionalidade do sistema legislativo, colocando em

14 A propósito, é de se registrar o esforço levado a efeito, em relação a este ponto, por Gabriel Divan (2015), que, em recente publicação, procurou lançar as bases de uma reflexão teórica destoante (ou, quiçá, dissidente) cujo principal mérito foi pensar acerca das possibilidades se fazer incorporar à criminologia crítica as discussões políticas contemporâneas que versam, fundamentalmente, sobre a ampliação e aprofundamento das liberdades democráticas. O autor observa, com acerto, que a circularidade da crítica criminológica (de inspiração marxista ou frankfurtiana) ao establishment político-criminal se deve, em grande parte, à hegemonia de uma suposição simplista e, no limite, equivocada, segundo a qual qualquer tentativa de se "fazer política criminal", desde o campo criminológico, resulta na assunção de um compromisso reformista que descaracteriza a própria identidade crítica dos discursos criminológicos, subordinando-os, com efeito, a um sistema heteronormativo e classista. Para o autor, a redescoberta da potência transformadora da crítica criminológica passa, necessariamente, pela sua aproximação com a teoria política (DIVAN, 2015, p. 174). 
xeque, consequentemente, o bom funcionamento do sistema jurídico-penal. Ademais disso, a ausência de uma reflexão analítica mais aprofundada acerca do fenômeno torna-se autoevidente na medida em que se constata que a maior parte das abordagens visitadas atribui ao populismo a mesma conotação pejorativa que se encontra sedimentada tanto no imaginário social, como no senso comum teórico. (LACLAU, 2013, p. 53).

Interessante observar, contudo, que esse descaso analítico não é uma exclusividade dos discursos criminológicos; a marginalização do fenômeno populista nas ciências sociais também pode ser percebida no campo da teoria política.

Como escreve Slavoj Zizek, "para a elite tecnocrática-liberal esclarecida, o populismo é inerentemente 'protofascista', o óbito da razão política, uma revolta disfarçada de explosões de paixões utópicas cegas" (ZIZEK, 2011, 279). Com efeito, independentemente da perspectiva teórica que antepara a sua análise, o populismo é quase sempre retratado como uma espécie de anomalia do sistema político-representativo que se manifesta através da difussão de discursos demagógicos e da emergência de lideranças carismáticas/autoritárias - geralmente constituídas à margem do "establishment" político-instucional - cuja aspiração mais elementar consiste na manipulação da vontade das massas a partir de um manejo utilitário, e eticamente reprovável, de seus medos e angústias (GOMES, 2001).

Definição similar, porém, ligeiramente mais refinada, pode ser encontrada no ensaio "Populismo" (1998), subscrito por Ludovico Incisa, que integra o dicionário político organizado por Norberto Bobbio. Com efeito, ao reconhecer o caráter excessivamente vago das definições comumente atribuídas à expressão, o autor opta por definir o populismo como uma espécie de fórmula política tendencialmente antidemocrática cuja "fonte principal de inspiração e termo constante de referência é o povo, considerado como agregado social homogêneo e como exclusivo depositário de valores positivos, específicos e permanentes" (INCISA, 1998, p. 980).

O autor sustenta a validade do seu entnedimento a partir da enumeração de inúmeros casos históricos a partir dos quais afirma ser 
possível contemplar a essência mesma da ideologia populista. Ao lembrarse do conteúdo das reivindicações de movimentos sociais tais como: os "diggers" ingleses, os "narodniki" russos, os getulistas brasileiros, dentre outros, o autor assevera que o populismo é, a um só tempo: (i) uma mobilização social constituída invariavelmente às margens dos canais institucionais vigentes; (ii) um apelo restauracionista que, manejado em momentos de aguda crise política, coloca a necessidade de se resgatar a "verdadeira política" a partir da exaltação de uma pureza cívica encarnada na figura do povo; (iii) um sistema político baseado na imprescindibilidade de uma liderança de tipo carismático e de um grupo de notáveis capazes de interpretar a vontade e o espírito do povo (INCISA, 1998, p. 983). O caráter antidemocrático do populismo, conforme observa o autor, decorre a feição enviesada do igualitarismo que postula. Diferentemente do igualitarismo liberal democrático, supostamente universal, conciliador e inclusivo, o igualitarismo populista baseia-se num discurso político radical a partir da qual o povo constitui-se a partir da exclusão/negação do seu contrário, isto é, do "corpo estranho que é preciso destruir fisicamente ou expulsar" (INCISA, 1998, p. 982)

Dentre as mais célebres análises do fenômeno realizada no âmbito do cenário teórico brasileiro, figura aquela referendada por Francisco Correia Weffort. No clássico "O Populismo na política brasileira” (1978), o autor propõe a atualização do sentido tradicionalmente atribuído à expressão a partir do abandono da perspectiva estruturalista ${ }^{15}$ que, desde a década de trinta, vinha fundamentando, de forma predominante, as análises relacionadas ao tema. Segundo Weffort, o populismo - enquanto fenômeno político - transcende os limites da explicação estruturalista adotada por,

15 A perspectiva político-estruturalista, defendida, dentre outros autores, por Gino Germani, defende a necessidade de se produzir inferências sociológicas através da análise das consequências políticas resultantes do fluxo migratório rural/urbano verificado durante interstício dos anos de 1870 e 1914, período histórico definido por Geoffrey Barraclough como "democracia das massas" e conhecido, sobretudo, pelo advento do direito ao sufrágio (masculino) universal: fato que permitiu a incorporação de grandes contingentes populacionais a uma cena política tradicionalmente dominada por setores das oligárquicas rural e industrial (GERMANI, 2010, p. 162; BARRACLOUGH, 1964, p. 119). 
dentre outros autores, Gino Germani (LACLAU, 2013, p. 34), de tal modo que, atualmente, ilustra a "forma mentis" de uma política baseada na conjugação de três fatores específicos: (i) repressão estatal; (ii) manipulação política e (iii) satisfação de demandas populares oriundas, sobretudo, dos grupos de trabalhadores assalariados.

Neste sentido, para Weffort, o populismo manifesta-se como um jeito ambiguo de fazer politica, vez que representa: (i) tanto um modo de realização dos interesses propugnados pelas massas perifericamente localizadas, (ii) como um estilo de governo mobilizado justamente para o seu controle (WEFFORT, 1978, pp. 62-63). Abdicando, em definitivo, do emprego da categoria dominaça ${ }^{16}$, o autor sinalizará a sua preferência em descrever o fenômeno por intermédio da metáfora da "aliança" (WEFFORT, 1978, p. 75). Neste sentido, Weffort dirá que uma política de corte populista representa, no sentido mais elementar, uma relação política ${ }^{17}$ cujo escopo é a preservação hegemônica dos interesses das classes dominantes mediante a realização de "algumas aspirações básicas" provenientes das classes populares (WEFFORT, 1978, p. 76). Independentemente das inovações constantes da abordagem preconizada pelo politólogo brasileiro (cujo trabalho indubitavelmente se opõe àquelas abordagens mais tradicionais que reduzem a complexidade do fenômeno ao equipará-lo a uma mera técnica ou estratégia de manipulação das massas ${ }^{18}$ ),

${ }^{16}$ Categoria que dominou grande parte das primeiras análises políticas elaboradas acerca do fenômeno populista (GOMES, 2001, p. 34).

17 O conceito de "relação política", no âmbito do presente estudo, assume a conotação sugerida pela seguinte proposição: “(...) relação é o nome de um vínculo objetivo que confere lugares específicos aos objetos heterogêneos constituídos no interior de um espaço discursivo" (LOPES, 2015b, p. 155).

18 Embora sua obra interpele de forma crítica os movimentos populistas brasileiros, Weffort não deixa de reconhecer que a mobilização do povo no interior dos mais variados discursos sociais denota a mais bem-acabada expressão da força política do princípio da soberania popular. É dizer, se de um lado o povo teria como manifesto destino ter a sua vontade instrumentalizada conforme os desígnios assentados pelas elites políticas, de outro, nenhuma ação política intentada no âmbito da esfera pública poderia ser considerada legítima, sob o ponto de vista democrático, se de dele prescinde. Conforme se infere das análises referendadas por Weffort, o estudo de movimentos tipicamente populistas desvela 
o populismo, "per se", (ainda que considerado um fenômeno estritamente vinculado ao período da democratização do país, sobretudo ao processo de integração das massas à política - (WEFFORT, 1978, p. 26)) continua sendo representado como uma forma limitada/disfuncional de se fazer política. Neste sentido é deveras ilustrativo o excerto:

[o populismo] é uma pobre ideologia que revela claramente a ausência total de perspectiva para o conjunto da sociedade. Não se poderia esperar mais de uma pequena burguesia que se assimila o comportamento do lumpen e de um operário que se expressa de maneira pequeno-burguesa. A massa se volta para o Estado e espera dele "o sol ou chuva", ou seja, entrega-se de mãos atadas aos interesses dominantes. (WEFFORT, 1978, p. 36)

É interessante observar, no entanto, que na ciência política contemporânea irrompem vozes a indicar a existência outras leituras possíveis acerca do fenômeno populista.

A politóloga inglesa Margareth Canovan (1999), autora de diversos ensaios sobre a temática do populismo, também produziu, nas últimas décadas, uma série bastante interessante de reflexões sobre o fenômeno populista. No ensaio "Trust the People! Populism and the Two Faces of Democracy" (1999), a autora propõe - num esforço análogo àquele realizado por Ernesto Laclau - compreender o populismo não mais como uma forma patológica de mobilização política, mas, ao invés disso, como um traço característico e irredutível das democracias contemporâneas. Nesse sentido, é sintomático o questionamento formulado pela autora logo no início da obra Populism (1981): “se as noções de 'poder popular' e 'decisão popular' são centrais para a democracia, porque os populistas não

o paradoxo constitutivo das formações de massa, que, no que diz respeito a sua iniciativa para a ação política, são essencialmente independentes das estruturas político-partidárias, porém tendencialmente predispostas a se deixarem controlar pelos mais refinados modos de se fazer política (WEFFORT, 1978, p. 27). 
são reconhecidos como os verdadeiros democratas que alegam ser?” (CANOVAN, 1981, p. 9).

Sem recorrer a um idealismo romântico e ao mesmo tempo perigoso, que sustenta a possibilidade de um autogoverno (v.g. autonomismo) alheio a todo e qualquer tipo de intervenção jurídicoinstitucional $^{19}$, Canovan propõe compreender o populismo como uma faceta da política democrática que se desenvolve em torno de uma disputa interminável pela capacidade de reinvenção da própria noção de povo. De acordo com o horizonte de sentido defendido pela autora, o populismo pode ser compreendido um movimento político baseado no apelo ao povo contra determinadas estruturas de poder, ideias e valores dominantes (CANOVAN, 1999, p. 5).

Essa potencialidade analítica que se encerra na ideia de populismo não deveria ser de todo estranha àqueles criminológicos, uma vez que, sob o pretexto de se realizar democraticamente os anseios do povo metaforicamente representado por um conjunto articulado de grupos sociais (p. ex. ambientalistas, feministas, movimentos negro e LGBT etc.) , a tutela jurídico-penal tem sido demandada, com frequência, por grupos sociais localizados mais à esquerda no espectro politico-ideológico. Veja-se, portanto, que o discurso populista não é necessariamente um discurso de natureza institucional que expressa um "novo jeito de governar"; ele pode representar, também, uma "forma particular de demandar", de articular demandas candentes e oriundas dos mais diversos grupos sociais. Mas não só. Segundo entendimento expresso pela autora, a própria noção de povo

19 Tal intento depreendido da análise do projeto teórico desenvolvido pelos filósofos Antonio Negri e Michael Hardt, para quem a "multidão", como ator histórico privilegiado, representa não menos que a encarnação do princípio revolucionário do "ser contra" que, a um só tempo, permitiria a reunião de diferentes lutas políticas em torno de um objetivo comum (v.g. a deserção universal) e daria ensejo à constituição de um sujeito emancipatório (v.g. a multidão), cuja ação seria capaz de fazer ruir o governo biopolítico exercido pelo Império transnacional constituído de instituições públicas e empreendimentos privados cujo poder desconhece a existência de limites geográficos (HARDT; NEGRI, 2001, pp. 436-437). 
ainda abriga um impulso anti-institucional ${ }^{20}$ salutar capaz de representar não apenas uma força reacionária capaz de canalizar ressentimentos e animosidades, mas, também, uma forte vontade social de autodeterminação e superação da alienação e da apatia políticas que acompanham os debates públicos na atualidade (CANOVAN, 1999, p.10).

Atendendo aos propósitos deste escrito, gostaríamos de sustentar agora amparados nos escritos teóricos de Margaret Canovan - que o populismo pode representar um movimento político, um discurso libertário, contrário, pois, às tendências de expansão do direito penal e de banalização das garantias constitucionais, máxime as de natureza processual penal. Em nosso auxílio, recorreremos a um exemplo específico consubstanciado nos diversos movimentos organizados, ao longo do ano de 2015, desde o campo da sociedade civil, que se posicionaram contrariamente às propostas legislativas de redução da maioridade penal. Essa verdadeira démarche, pinçada dentre vários outros episódios de resistência ao avanço do discurso penal, é bastante ilustrativa, sobretudo na medida em que ajuda a perceber que, para além da sua usual conotação, o apelo ao povo pode representar, a depender das demandas políticas por ele articuladas, um discurso emancipatório, contrário, pois, ao establishment repressivo.

Caberia anotar, no ponto, que as carências analíticas verificadas no âmbito do debate criminológico contemporâneo acerca do populismo são

\footnotetext{
${ }^{20}$ Para Laclau, um dos traços característicos de toda e qualquer formação que se diga populista é o seu apelo ou viés anti-institucional. Qualquer que seja a predisposição ideológica das demandas que compõem a vontade coletiva (popular), sempre se percebe neste processo de articulação de diferenças "um chamado aos despossuídos" (LACLAU, 2013, p. 188). Obviamente, como estamos operando a presente análise a partir do esquadro teórico pós-estruturalista, estamos assumindo, de antemão, que o sentido de "despossuídos" variará consideravelmente nos muitos contextos a partir dos quais a expressão é mobilizada. Isso se torna claro quando pensamos que o apelo às vítimas, nos discursos político-criminais, costuma representar-lhes como "cidadãos despossuídos de segurança". De outro lado, o discurso criminológico (crítico) costuma representar a clientela habitual do sistema de justiça criminal como "sujeitos despossuídos de garantias jurídico-penais". Vê-se, aqui, àquilo que Laclau chama, em sua teoria sobre o populismo, de significantes flutuantes, significantes cujo sentido é disputado por projetos hegemônicos rivais (LACLAU, 2013, p. 198).
} 
também verificadas em inúmeras um número bastante considerável de análises oriundas do campo da ciência política. A propósito, Benjamin Arditti observa que grande parte da teoria política contemporânea (e este diagnóstico abarca, sem embargo, as teorias criminológicas de orientação crítica), tem ignorado, solenemente, o estudo das relações possivelmente existentes entre as várias formas de populismo e os movimentos sociais de orientação progressista, que, partindo de mobilizações populares fundadas na defesa dos direitos humanos, pressionam o Estado e suas instituições mirando o estabelecimento ou a ampliação de limites às políticas de orientação repressiva (ARDIT'TI, 2003, p. 20).

Avançando em nossa análise e diante dessas constatações iniciais, pensamos que também seja de alguma valia repensar os sentidos correntemente atrelados à noção de populismo penal à luz da teoria de Ernesto Laclau.

\section{REINVENTANDO O POPULISMO: BREVES APONTAMENTOS SOBRE O PENSAMENTO POLÍTICO DE ERNESTO LACLAU}

Em “A Razão Populista” (2013), Laclau propôs - como já tivermos a oportunidade de esclarecer - a adoção de uma nova perspectiva de análise em relação aos debates realizados em torno dessa tão controversa temática. Propondo inverter o sinal negativo historicamente atrelado à expressão, o autor buscou pensar no que, efetivamente, consiste este desprestigiado fenômeno político e qual é, com efeito, a sua especificidade. Poderia o termo representar algo além de uma espécie de rótulo difamatório? Eis o oportuno questionamento suscitado pelo politólogo argentino.

Rompendo com uma longa tradição teórica que procura explicitar as bases de compreensão do fenômeno a partir de uma série de proposições derivadas da primeira fase da escola da psicologia social do século XIX, Laclau sugere ser possível - para além de necessário - realizar outra leitura acerca do fenômeno populista, uma leitura que, resgatando-o de sua "posição marginal no interior dos discursos das ciências sociais" (LACLAU, 2013, p. 55), tende a fazer com que ele deixe de ser considerado, em si, como 
um traço característico de um movimento político anômalo e irracional para passar a ser concebido como a própria condição de possibilidade, organização e realização das demandas populares em contextos democráticos $^{21}$ (LACLAU, 2013, p. 240). Ao recusar tratar do fenômeno como se ele representasse, muito simplesmente, uma estratégia política eticamente reprovável, Laclau prefere expressá-lo como uma lógica política através da qual: diferentes demandas sociais são articuladas em cadeias de equivalência para, juntas, representarem uma identidade política coletiva, uma totalidade discursivamente estruturada, porém precária e irremediavelmente contingente, que recebe o nome de povo.

Em síntese, para Laclau, o fenômeno "populista" expressa, no limite, uma lógica política que está às voltas com a constituição de uma identidade política coletiva baseada na expressão de uma vontade popular ${ }^{22}$.

${ }^{21}$ Nesses termos, o populismo deixa de ser compreendido como um mero epifenômeno da práxis política contemporânea para ser considerado como lógica constitutiva da mesma, não sendo ele, destarte, "necessariamente incompatível com os próprios regimes democráticos contemporâneos" (MENDONÇA e PEIXOTO, 2014, p. 49).

22 Já que o rigor analítico constitui traço característico das reflexões referendadas por Ernesto Laclau, impende esclarecer, aqui, o sentido que a expressão "identidades políticas coletivas" e, consequentemente, qual é sua serventia no âmbito do estudo proposto. Com efeito, legatário do pensamento gramsciano, Laclau sustenta - através dos conceitos de "identidades populares" e "identidades políticas coletivas" - a necessidade de se abandonar a concepção ortodoxa derivada do marxismo clássico que identifica a "classe" (operária/ proletária) como sujeito político par excellence. Para Laclau, o conceito de "classe", ao ser concebido previamente às lutas políticas concretas, não logra explicar a heterogeneidade radical das demandas e subjetividades políticas que habitam as arenas políticas contemporâneas. Nesse contexto, os conceitos de "identidades populares" e "identidades políticas coletivas" (sinonímias que se referem à noção "totalidades articuladas de diferenças") aproximam-se da noção gramsciana de "vontade coletiva", que, por sua vez, designa a etapa final do processo de constituição hegemônica dos sujeitos políticos a partir da aglutinação de uma pluralidade de identidades sociais tipicamente heterogêneas. Embora compreendam, de modo muito similar, a dinâmica que envolve o processo de constituição das identidades políticas, Laclau e Gramsci discordam relativamente ao papel da classe operária neste processo. Enquanto que para Gramsci a classe operária - a classe fundamental da sociedade - deveria funcionar, invariavelmente, como uma espécie de referente estrutural necessário a coordenar toda a luta política pela hegemonia (GRAMSCI, 2000, p. 232); para Laclau a classe operária representa, no limite, mais uma identidade 
O sentido atribuído pelo autor ao termo caracteriza-se, pois, na antípoda do sentido compartilhado pela maior parte trabalhos criminológicos que versam sobre a temática do "populismo punitivo", textos onde o povo emerge como uma espécie de entidade objetiva ${ }^{23}$, dotada de um sentido transparente e determinado em última instância: seja, de um lado, como povo irracional que demanda, inconsequentemente, por mais punição; seja, de outro, como povo cujo destino manifesto é servir, voluntariamente, como massa de manobra, as aspirações eleitorais de políticos profissionais bem versados na arte de guindar o significante Lei Penal à condição de solução universal de todo e qualquer conflito social.

particular sujeita aos processos de articulação. Com efeito, para Laclau, não é possível assegurar de antemão nem o protagonismo da classe operária com relação à condução dos processos de transformação social, nem o fato de que as articulações por ela eventualmente coordenadas terão um sentido necessariamente progressista (LACLAU; MOUFFE, 2015, pp. 134-136). As considerações críticas referendadas por Laclau acerca do conceito gramsciano de "vontade coletiva" poderiam ser transladadas para o campo do debate criminológico que discute, ainda hoje, as "razões" da tendência criminalizadora denominada de "esquerda punitiva". As proposições do politólogo argentino demonstram, de efeito, ter algum potencial para resgatar a criminologia crítica brasileira do estado de torpor em que se encontra em que se encontra (e.g. este "torpor analítico" é representado claramente pela tautologia das análises patrocinadas por um conjunto considerável de narrativas criminológicas de inspiração crítica), sobretudo em função da sua aparente incapacidade de refletir, a partir da ortodoxia marxista, sobre os motivos pelos quais diversos movimentos sociais aparentemente progressistas aderiram, sobretudo nas duas últimas décadas, a uma ideologia punitivista. Seria preciso lembrar, no ponto, novamente com Laclau, que na medida em que as identidades políticas não estão determinadas "a priori”, é dizer, na medida em que são construídas, contextualmente, a partir do estabelecimento de relações/ articulações hegemônicas, não poderia haver garantia alguma de que tais movimentos - malgrado os seus ideais genuinamente progressistas - não fossem buscar pelo reconhecimento e a visibilização das suas demandas junto à hegemonia do discurso punitivo. Neste sentido, poderia ser mais útil à tarefa de reversão dessa aproximação a identificação e desconstrução (no sentido derridiano) das articulações hegemônicas que transformaram lutas democrático-populares marcadamente antiestablishment em novas plataformas de legitimação política do sistema de justiça criminal.

${ }^{23} \mathrm{O}$ conceito de "objetividade" faz referência, no ponto, à pressuposição de que a identidade popular constitui, ela própria, uma identidade política extradiscursiva, isto é, positiva, passível de ser apreendida, em última instância, pelos discursos que afirmam retratá-la. 
Nessa medida, o populismo, agora ressignificado sob o ponto de vista analítico, adquire um novo potencial heurístico, já que se importará em descrever as nuances do processo de construção e articulação dos sentidos das identidades políticas mobilizadas pelos discursos legislativos de corte criminalizador. Essa nova perspectiva de análise permite, desde o nosso ponto de vista, o aprofundamento da crítica ao assim denominado movimento de expansão do direito penal, sobretudo na medida em que passa a admitir a necessidade de se considerar - como variável constituinte da equação populista - o fato de que o povo não é nem um datum natural, nem uma identidade política cuja existência depende, necessariamente, de uma lógica ou forma específica de configuração institucional ${ }^{24}$; de efeito, a noção de povo constitui, em termos laclaunianos, uma realidade política concebida discursivamente cuja finalidade é funcionar como nome de uma totalidade formada por elementos discursivos heterogêneos articulados precária e contingentemente, porém de forma equivalente - em face um elemento externo que se lhes apresenta como um inimigo. Outra especificidade da formação populista defendida por Laclau diz respeito à compreensão de que o povo não pode ser identificado como "populus", isto é, como corpo político homogêneo formado por um todo juridicamente definível, tampouco como plebs, isto é, como grupo de desprivilegiados, alijados da possibilidade/capacidade de participação efetiva na esfera política. Destarte, para cogitar-se da existência do povo de que trata a teoria laclauniana sobre o populismo precisamos abdicar da oposição plebs versus populus $^{25}$ : "precisamos de uma plebs que reivindica ser o único populus legítimo, uma parcialidade que quer funcionar como totalidade da comunidade" (LACLAU, 2013, p. 134).

Em suma: para os propósitos deste escrito, o povo, a despeito da sua profícua capacidade significativa, assumirá a tarefa de representar, na

\footnotetext{
24 Ter o presente argumento em mente é importante para se possa compreender a razão pela qual o populismo é retratado como uma lógica política cuja finalidade é "nomear" uma totalidade impossível, porém necessária, comumente expressada pela ideia de comunidade. O que interessa extrair da proposição assinalada é, com efeito, a afirmação de que o povo "não expressa uma unidade previamente dada" (LACLAU, 2013, p. 182).

${ }^{25}$ Defendida, dentre outros, por Giorgio Agamben (AGAMBEN, 2015, p. 35).
} 
condição de significante vaz̧io ${ }^{26}$, o nome de uma totalidade (precária e contingente) constituída por elementos particulares articulados em uma cadeia equivalencial que, por sua vez, pressupõe - como condição de possibilidade - a existência de uma fronteira interna ao espaço social que divide, numa díade antagônica, o povo - que, como vimos anteriormente, emerge como nome que denota um conjunto de demandas sociais igualmente insatisfeitas - e o bloco de poder representado como responsável pela frustração daquelas demandas (democráticas) organizadas sob a égide de uma identidade política coletiva, uma identidade popular ${ }^{27}$.

À vista dessas considerações, parte importante de nossa proposta neste escrito consiste em assentar, em relação ao debate sobre o populismo penal, um pressuposto ontológico aparentemente estranho à sociologia do conflito, que de forma mais ou menos explícita, fundamenta a reflexão criminológica contemporânea acerca do fenômeno em questão, qual seja: o de que povo, em vez de representar um dado social objetivo e unívoco, vale dizer, o povo como sociedade que demanda punição), constitui uma categoria política cuja realidade é determinada pelos discursos que, operando como suplementos (no sentido derridiano), preenchem, contingentemente, essa falta

\footnotetext{
${ }^{26}$ Para Laclau um significante vazio não representa apenas um significante sem significado. Tal entendimento ilustra, para o politólogo argentino, uma forma inadequada de abordar a tese lacaniana da autonomia do significante frente ao significado. Para Laclau, um significante sem significado é apenas um "ruído" incomunicável. Quando faz alusão a noção de significante vazio, Laclau tem em mente algo diferente: “(...) quando falamos de 'significantes vazios' [...] queremos dizer que existe um lugar, no sistema de significação, é que constitutivamente irrepresentável. Nesse sentido ele permanece vazio, mas este é um vazio que pode ser significado, pois estamos lidando com um vazio no interior da significação" (LACLAU, 2013, p. 166).

${ }^{27}$ Com o intuito de tornar claros os contornos da realidade social que a subjaz esse conjunto um tanto abstrato de proposições, Laclau indica dois traços considerados essenciais a toda e qualquer espécie de formação populista, seja ela considerada de direita, seja, na antípoda, reputada como de esquerda: i) o populismo expressa, em qualquer das suas muitas possibilidades configuração, um impulso anti-institucional cujo propósito maior consiste em desafiar a "ordem habitual das coisas"; ii) este desafio pressupõe, por sua vez, que "os excluídos dos canais políticos tradicionais" sejam instados publicamente a criar uma nova ordenação social (LACLAU, 2013, p. 187).
} 
constitutiva das identidades políticas ${ }^{28}$. O entendimento deste último ponto é de suma importância para que se chegue a uma compreensão adequada acerca do verdadeiro giro copernicano proposto pelo autor, afinal "não há nada de automático sobre a emergência do 'povo'; ao contrário, o 'povo' é produto de um complexo processo de construção social que, entre outras possibilidades, pode não alcançar o seu objetivo" (LACLAU, 2013, p. 285).

Destarte, determinado a levantar o embargo teórico que pende, ainda hoje, sobre o fenômeno populista, o politólogo argentino buscará desconstruí-lo, no sentido forte do termo, através da ressignificação das suas principais conotações pejorativas (populismo como retórica, populismo como demagogia, populismo como estratégia de dominação das massas; populismo como fenômeno vago e indeterminado quanto ao público a que se dirige etc.), tudo a fim de desenvolver uma nova perspectiva analítica que "transcende tudo o que possa ser caracterizado como [uma simples] aplicação de uma categoria" (LACLAU; MOUFFE, 2015, p. 36).

Outro problema que se observa com relação aos sentidos comumente atribuídos pela criminologia ao fenômeno populista e que estaria a sugerir a sua reinterpretação à luz dos postulados teóricos laclaunianos diz respeito a sua aparente incapacidade dessa vertente teórica para apreender a complexidade das relações sociais que se desenvolvem no âmbito das democracias contemporâneas, um problema que tem ocupado grande parte das modernas investigações da ciência política.

É que as acepções que servem de base para as abordagens anteriormente elencadas privilegiam uma interpretação limitada da dinâmica dos movimentos que têm lugar na arena política, apresentando-a, destarte, como uma espécie de "mise-en-scène" em que as lutas sociais (e populares) são eclipsadas, a priori, por uma disputa política mais abrangente que se estabelece entre os membros de uma aristocracia política cujo único

\footnotetext{
${ }^{28}$ Eis, fundamentalmente, o ponto que distingue a presente abordagem sobre o populismo punitivo daquelas elencadas: estamos assumindo como pressuposto analítico o fato de que o "populismo" enquanto tal representa um fenômeno político construído discursivamente e cujo significado variará conforme "the social constructs of the actors involved" (YOUNG, 2004, p. 15).
} 
propósito é manipular, consoante as suas próprias ambições, a vontade das massas (MOUFFE, 1996, p. 172).

Ademais disso, inserido no circuito teórico da crítica criminológica ao populismo, o povo, entendido aquém da sua potencialidade analítica, parece representar, simplesmente, o resultar final de uma congregação de indivíduos politicamente apáticos e aparentemente incapazes de "discernir entre o seu interesse e o interesse daquele que supostamente os enganam" (MENDONÇA; JUNIOR, 2014, p. 125). Esse tipo de análise, no entanto, num momento em que as teorias política e sociológica refletem acerca das formas possíveis de se reinventar os sentidos da democracia contemporaneamente $^{29}$, tem se mostrado, no mínimo, contraprodutiva (AGAMBEN, 2015, p. 37; SOUSA SANTOS, 1998, p. 43). Mais. Esse tipo de leitura costuma iluminar a discussão que opera, com certo maniqueísmo, a partir da pressuposição de que o Estado e suas instituições são como que exclusivamente responsáveis pela produção e manutenção de todas as relações de desigualdade e formas de dominação. Tal argumento, no entanto, não reúne, sob o ponto de vista empírico, condições mínimas de sustentação. Existem razões suficientes a justificar a adoção de um entendimento contrário. Relativamente a essa questão, Laclau e Mouffe lembram que o "Estado não é um meio homogêneo, separado da sociedade civil por um dique, mas um conjunto desigual de agências e funções integradas apenas relativamente pelas práticas hegemônicas que têm lugar no seu interior" (LACLAU; MOUFFE, 2015, p. 268). Significa dizer, com efeito, numa aproximação com a perspectiva foucaultiana, que o Estado, enquanto tal, não pode ser concebido, apenas, como um "instrumento de

${ }^{29}$ O que está em jogo, com efeito, é a superação do marco conceitual clássico segundo o qual a democracia representa, no limite, um arranjo institucional cujo proposto maior é observada a existência de algumas condições externas ao processo eleitoral, tais como: a liberdade de impressa e o respeito à pluralidade política de opiniões - constituir um governo legítimo formado por indivíduos escolhidos através de uma competição limpa, igualitária, inclusiva e decisiva, pela conquista do voto livre e direto. Esta é, no limite, a célebre definição da "democracia enquanto procedimento", elaborada, inicialmente, por Schumpeter e aprimorada, posteriormente, por Anthony Downs (SCHUMPETER, 1961, p. 56; DOWNS, 1999, p. 82). 
dominação de classe" ou, ainda, como "um monstro frio" (FOUCAULT, 2008 , p. 520). Não descuidamos do fato de que todos esses predicativos encontram de certa forma eco na realidade, afinal, ao menos em matéria de controle penal, não nos parece haver exagero no diagnóstico elaborado por Luigi Ferrajoli que atribui aos estados ocidentais, no tocante à questão dos direitos humanos, a alcunha de "lupus artificialis" (FERRAJOLI, 2010, p. 861). Todavia, não cabe olvidar do fato de que o Estado (e suas instituições) também pode ser compreendido como uma "realidade compósita", como um "efeito móvel de um regime de governamentalidades múltiplas" (FOUCAULT, 2008, p. 521) e, finalmente, como uma "superfície de [inscrição e] emergência de antagonismos democráticos" (LACLAU; MOUFFE, 2015, p. 268). É dizer, ao abdicarmos daquele conjunto de pressuposições derivadas daquilo que Foucault chamou de "fobia de estado" (FOUCAULT, 2008, 259), torna-se lícito pensar o Estado como um meio indispensável de se efetuar importantes avanços em relação à garantia, ampliação e proteção de direitos frequentemente contestados pela sociedade civil. Nesse particular, julgamos pertinente a menção às seguintes leis federais: Lei $\mathrm{n}^{\circ} 9.046 / 95$, que obriga os estabelecimentos prisionais brasileiros destinados ao público feminino a disporem de berçário e local onde as condenadas possam amamentar; Lei $\mathrm{n}^{\circ}$ 9.460/97, que garante aos condenados com mais de sessenta anos de idade o direito ao recolhimento em estabelecimento prisional adequado às suas condições pessoais; Lei $\mathrm{n}^{\circ}$ 10.713, que acresce ao rol de direitos do preso a emissão de atestado anual de cumprimento de pena; Lei $\mathrm{n}^{\circ} 11.942 / 09$, que assegura às mulheres encarceradas tratamento médico especializado durante os períodos de prénatal e pós-parto; Lei n ${ }^{\circ} 12.245 / 10$, que dispõe sobre a obrigatoriedade de instalação de salas de aulas destinadas a cursos do ensino básico e profissionalizante nos estabelecimentos penais brasileiros e, finalmente; Lei $\mathrm{n}^{\circ} 13.163 / 15$, que trata da criação das estruturas necessárias à implementação do ensino médio em todas as penitenciárias situadas no território nacional.

Ainda nessa linha argumentativa, é importante lembrar que a sociedade civil também é palco de inúmeras relações de opressão, basta recordar, com efeito, dos emblemáticos resultados obtidos pelo pesquisador 
José de Souza Martins em seus vários anos de pesquisa sobre o fenômeno dos linchamentos no Brasil (MARTINS, 1996, p. 16), dados que apontam para o crescimento exponencial da prática nas últimas décadas.

À luz dessas considerações é possível perceber que a crítica antiinstitucional (uma das mais exaltadas bandeiras do saber criminológico crítico de orientação marxista) pauta-se por conjunto de apriorismos que reduz, de forma absolutamente arbitrária, a complexidade das lutas pela capacidade de significação do Estado e suas instituições.

Sem embargo, ao denunciar o caráter manipulador do discurso (parlamentar) populista, a crítica criminológica termina - ainda que de forma involuntária - abrindo espaço para uma perigosa inflexão da esfera pública de discussão. É que a contestação do perfil demagógico dos discursos legislativos parece sugerir - como alternativa a essa espécie de anomalia decorrente do subdesenvolvimento do ideal democrático representativo - a profissionalização das instâncias de deliberação política, o que implicaria a gradual substituição dos agentes políticos por tecnocratas bem versados na arte de governar, outra concepção no mínimo questionável sob o ponto de vista democrático. A propósito disso, cabe recordar que ao justificar a escolha da temática do populismo para desenvolver suas teses sobre a lógica populista de formação das identidades políticas coletivas, Laclau parte do pressuposto de que a subestimação da importância do fenômeno está diretamente associada ao empobrecimento do imaginário político contemporâneo, uma vez que na sua denigração está implicada a "afirmação de que a gestão da comunidade cabe a um poder administrativo cuja fonte de legitimidade é o conhecimento apropriado daquilo que constitui uma boa sociedade (LACLAU, 2013, p. 27).

Coloquemos este último argumento à prova. A complexidade da construção populista, isto é, dos processos de articulação discursiva de demandas sociais heterogêneas cujo encadeamento permite o advento do povo como significante dotado da capacidade de mobilização e transformação social e institucional, traduz-se justamente no fato de que o fenômeno pode ser mais adequadamente representado na medida em que deixamos de enxergá-lo como uma ideologia programática (que buscara a realização de um determinado projeto de poder), e passamos a concebê-lo 
como uma lógica política de construção de identidades políticas coletivas em ambientes democráticos. Este novo enfoque permite-nos reelaborar, por exemplo, a crítica realizada por David Garland ao populismo punitivo. Lembremo-nos que ao tratar do perfil populista da política criminal estadunidense, o autor esboça alguma preocupação com relação ao estabelecimento de uma gradual prevalência dos discursos populares - aquilo que Alessandro Barrata denominou como everyday theories - sobre os discursos críticos de corte científico, sobretudo aqueles oriundos do campo acadêmico. Essa forma de colocar o problema denota, desde o nosso ponto de vista, um equívoco estratégico. É que a forma de elaboração da crítica, para além de tomar a noção de "discurso popular" como um dado social objetivo, lhe apresenta como espécie de signo representativo de uma fala desqualificada sob o ponto de vista técnico-jurídico. Caberia aqui mencionar, em atenção às premissas assentadas inicialmente, que nem todos os discursos qualificados como populares se articulam em prol da defesa de projetos políticos voltados à ampliação do horizonte criminalizador. O inverso também é verdadeiro: nem todos os esforços teóricos levados a efeito pelos criminólogos miram a elaboração de análises destinadas a refrear os excessos perpetrados pelo manejo indiscriminado do poder punitivo. Seria preciso notar, ainda, que tampouco o discurso acadêmico compartilha dessa pretensa unidade de sentido que, a pretexto de uma cientificidade autoproclamada, o colocaria em posição de vantagem sobre os discursos políticos. Essa tentativa, que de alguma forma faz lembrar a anedota protagonizada pelo Barão de Münchhausen, revela, por si só, o caráter ideológico dessa ofensiva que supõe ser possível depurar, completamente, o político do científico. No ponto, Paul Feyerabend dirá, ferinamente, que a intensidade da convicção demonstrada pelo racionalista, com relação à possibilidade de descrição da verdade através do manejo dos padrões conceituais apreendidos com o mestre, servirá como medida que atestará o seu próprio grau do comprometimento/engajamento político frente ao objeto estudado e ao contexto no qual este se insere (FEYERABEND, 2011, p. 40). Por óbvio, é necessário reconhecer que as iniciativas em torno do desenvolvimento de uma legislação penal de corte garantista costumam ser capitaneadas por um conjunto de experts (v.g. juristas, sociológicos, antropólogos, etc.); não 
obstante, a força política deste projeto jurídico-penal depende, inexoravelmente, do reconhecimento da sua legitimidade pelos mais variados grupos sociais. Por essa razão, a pretensão cientificista que versa sobre a necessidade de se reservar as decisões político-criminais a um grupo seleto e privilegiado de especialistas, sob o pretexto de serem eles os únicos sujeitos capazes de enunciar os procedimentos e princípios reguladores da coexistência humana, só pode ser qualificada, a nosso ver, como autoritária. Certamente, existem demandas populares que, sob o ponto da vista de uma determinada tecnicidade, podem parecer simplesmente infundadas, no entanto, se enxergamos o problema sob o ponto de vista políticodemocrático, não existem razões mínimas que justifiquem imunizar o saber dos especialistas face as demandas e aos questionamentos populares. Nesse sentido, escreve, com acerto, José Luis Díez Ripollés: “o saber políticocriminal - assim como o saber jurídico-penal que dele deriva - é, como o próprio nome indica, um saber político, razão pela qual é na arena política onde devem ser defendidos os seus postulados" (DÍEZ RIPOLLÉS, 2003, p. 197).

Por todas essas razões, seria preciso notar, aqui, a reversibilidade do potencial crítico que se encerra, sobretudo, nos discursos criminológicos de orientação crítica, que, interpelados desde outra perspectiva teórica, passam, agora, a representar, numa espécie de paralaxe, um terreno inóspito, árido, onde o movimento crítico enquanto tal é interrompido por uma espécie de cegueira que não deixa ver o populismo, e, por consequência, o fenômeno do "político", para além de uma conotação pejorativa acriticamente difundida que lhe apresenta como uma anormalidade política, como uma prática eticamente reprovável que visa, senão, o controle a manipulação das massas.

\section{POPULISMO PENAL OU PÂNICO MORAL?}


Evidentemente que qualquer proposta - por mais radical que seja de ressignificação do populismo no âmbito da criminologia contemporânea, não isenta a crítica da necessidade de revisar outros conceitos familiares, amplamente utilizados, porém raramente problematizados. Com isso queremos dizer que, se por um lado a ideia de povo que norteia o projeto teórico-político de Laclau representa um importante aporte para a compreensão do fenômeno do populismo penal, por outro, a sua assunção coloca algumas dificuldades que, reconhece-se, ainda devem ser mais bem trabalhadas.

Temos que considerar que o significante povo é produto de uma tensão irredutível entre determinadas demandas sociais. Portanto, a sua inserção na teoria política integra um movimento de revisão que se associava, independentemente da tradição metodológica ou epistêmica que se adote, a uma ontologia da massa como portadora de uma irracionalidade intrínseca. A época das massas será aquela em que o coletivo será perpassado por um conjunto estranho, sem dúvida, mas operativo, de uma entificação, ou melhor, de uma homogeneização da massa. Não à toa que Freud investirá sobre análise da "Psicologia das Massas" (2014). Tarde (2005), por sua vez, associará a violência (da massa) à mimese, continuando assim uma tradição herdada de Le Bon (2009), que interpreta a massa metaforicamente, através da sua associação à loucura. Em síntese, ao falarmos das massas estamos sempre diante de sujeitos coletivamente débeis, irracionais ou incapazes de precisar exatamente as suas atitudes. $\mathrm{O}$ que a criminologia faz, considerando as diversas matrizes alhures nominadas, é transferir este potencial irracional, esta verdadeira potência niilista, para as encruzilhadas entre política criminal e criminologia.

Esta encruzilhada na qual se encontram as pretensões "críticas" da criminologia resulta de um notável déficit politológico, imprime, naturalmente, que um fenômeno da política criminal, de tendências expansivas, seja imediatamente interpretado como populista. O grande problema é que uma reviravolta na ciência política, que exige a participação popular, seja de forma imediata, como as eleições ou propostas deliberativas diretas e não reflexivas, seja através do povo como o grande feixe centralizador de políticas públicas, cria um grande problema para justificar o afastamento do povo das 
decisões que envolvem políticas públicas de natureza penal/criminal. Em outras palavras, de fato, tão somente uma determinada tradição jurídica (a liberal) permitiria concluir-se, legitimamente, pelo afastamento do povo destas decisões acerca do sistema criminal. Não fosse assim, como poderia se justificar, exemplificativamente, a presença de jurados que produzem decisões político-criminalmente relevantes, isto é, decisões que não se tratam de posturas teleológicas abstratas e determinantes para o devir, mas que produzem efeitos diretamente sobre os jurisdicionalizados?

Esta questão, por mais comezinha que possa parecer, tem o condão de apresentar este epicentro da indeterminação conceitual sobre o povo, quando existe um investimento político-criminal. Afirmar que o populismo penal corresponde, inexoravelmente, à utilização do povo como massa de manobra, seja para fins eleitoreiros, seja para fins de consumo, não oferece melhores pistas do que aquelas já ventiladas por uma matriz psicológicopolítica obsedante. Em não sendo assim, quais traços poderíamos encontrar para em primeiro lugar redefinir e, subsequentemente, apresentar novos potenciais político e criminologicamente catéxicos?

Fundamentalmente, as leituras criminológicas críticas, como regra, elencam o populismo penal a partir de um conjunto de características que tendencialmente o apresentam como: a) um defeito contemporâneo do sistema de justiça criminal, o que, diante de uma leitura "otimista" do sistema criminal, autorizaria a envidarem-se esforços para a correção do problema; b) uma prática político-criminal que atrela diversos atores sociais em uma cruzada contra diversos bodes expiatórios, o que poderia ser explicado diante das já exaustivas explicações derivadas do interacionismo simbólico, especialmente a partir dos escritos de Howard Becker (2008) relativamente às cruzadas morais. Nesta situação, o termo populismo carregaria consigo uma variante categorial que obrigatoriamente imputaria ao Parlamento, assim como a outras instâncias igualmente relevantes, o papel de "empresários morais atípicos" (Becker, 2008); c) um discurso anêmico, pautado a partir de um marco zero de significância (ou seja, arquitetado a partir de uma ferramenta metodológica estruturalista), significado unilateralmente, tão somente a partir de um contra-discurso. Em outras palavras, o populismo, neste contexto, seria identificado com o reverso do 
discurso crítico, o que, apesar de oferecer qualquer contributo do ponto de vista heurístico, peca pela incapacidade de se estabelecer "nós" ou, como diria Castoriadis, "magmas de significação" (CASTORIADIS, 1982).

Ultrapassadas estas premissas falhas do discurso criminológico crítico, que poderiam ser nominadas como verdadeiros "obstáculos epistemológicos", como apontaria Bachelard, (percebe-se claramente o apego destas matrizes à lei bachelardiana da bipolaridade dos erros), há que se avançar.

O populismo penal não pode ser tão somente a estagnação de um discurso pretensamente crítico, que identifica na realidade operativa do sistema punitivo (portanto, uma característica nociva deste modelo), que procura explicar as práticas punitivas contemporâneas (num retorno ao empreendedorismo moral beckeriano) através de uma noção que emerge de si mesma, tal como um Barão de Münchausen que, ao puxar seus próprios cabelos, se salva da areia movediça. O que podemos perceber claramente é que a atribuição do adjetivo "punitivo" ao termo populismo, malgrado a sua disseminação na doutrina criminológica crítica, oferece apenas um campo restrito de análise que se submete a um conjunto de reflexões psicológicojurídicas de natureza autoritária ${ }^{30}$, diga-se de passagem.

Outra incongruência presente no discurso criminológico crítico contemporâneo reside na sua incapacidade para verificar a instabilidade semântica inerente à própria noção de povo. Ora, se a concepção política tradicional compreende o populismo como fenômeno denotativo da irracionalidade intrínseca das massas, como poderia a criminologia crítica sustentar a legitimidade de movimentos sociais que, por exemplo, reclamam direitos sociais? Afinal, como poderiam as massas irracionais formular pretensões legítimas?

Se de fato há um problema nesta transposição imediatista do conceito de povo (ou massa) desde uma tradição autoritária, o próprio populismo em matéria penal deve ser repensado. O populismo não pode

\footnotetext{
30 A carência da reflexão criminológica é cristalina neste ponto. Não pode ser válido um discurso que se pretende minimamente crítico quando se aceita, sem questionamentos, conclusões tais como aquelas proferidas por Gustave Le Bon e Gabriel Tarde, especialmente.
} 
ser pura e simplesmente ativado através de uma adjetivização qualquer (populismo punitivo, político, oligárquico etc.), o que lhe renderia vínculos e eficácia em um determinado segmento social ou, ainda, podendo ser balizado por quaisquer blocos de cientificidade. A redução da crítica criminológica a um aspecto centralizado no incremento das potencialidades punitivas recobre apenas uma das faces da moeda.

É mais do que óbvio que a política criminal atenderá aos mais diferentes interesses, incluindo-se aqui aqueles descritos e criticados sob o rótulo de ampliativos da tutela penal. É natural que a política criminal flerte com os meios de comunicação social. Parece-nos sintomático, igualmente, que movimentos pró-vítimas ganhem corpo na atual conjuntura política. Contudo, se bem compreendidas as bases do populismo, tal como Laclau as apresenta, força convir que a constelação das demandas sociais insatisfeitas convergirão para que tenhamos significantes-vazios, isto é, grandes demandas vazias que poderão ser preenchidas com os mais diversos conteúdos; sejam estes conteúdos penais, cíveis, administrativos, etc., dependerá muito menos do fenômeno descrito pela criminologia crítica como populismo penal do que da própria operatividade do termo populismo. Ou seja, Laclau nos oferece a oportunidade de pensar o conceito em perspectiva através de sua inextricável conjunção com a ideia de democracia.

O populismo carrega consigo a marca da permanência, isto é, constitui-se como um modo-de-ser da socialidade contemporânea, ao menos se tivermos presentes as condições de instalação de uma plataforma governamental democrática, que pressupõe, como alertou há bom tempo Lefort (1991), um local vazio do poder. Com efeito, para podermos levar em consideração como ocorre a instalação do povo como elemento fundamental nas democracias ocidentais contemporâneas, temos de abdicar dos ensinamentos provenientes daquilo que chamamos anteriormente de matriz do pensamento psicológico-jurídico autoritário, que concebe no local do poder uma determinada encarnação, uma individuação dos centros de poder, que, via de regra, eram identificáveis, que possuíam um nome, que se constituíam como o Um-ocupante do poder. Rejeitadas estas concepções anacrônicas, o populismo poderá finalmente ser compreendido não mais 
como um defeito, mas sim como traço indicativo da vitalidade democrática das sociedades contemporâneas.

Contudo, resta ainda a enfrentar o segundo desafio lançado. Que são estas campanhas de lei e ordem, que são estas políticas criminais que convergem de certa forma em prol de um incremento da punitividade no Brasil. Sem recorrer à simplista e deslocada tese do "populismo penal", resta-nos examinar como tais demandas podem ser integradas, como elas podem ser justapostas, trazendo como refluxo o assoberbamento do sistema de justiça criminal. Não restam dúvidas de que as demandas populares insatisfeitas podem ser cooptadas, embora o fenômeno da expansão do sistema criminal não possa ser unicamente explicado através de uma espécie de "sequestro institucional de expectativas ou pretensões sociais". Do contrário cairíamos no modelo de cruzada moral.

Talvez fosse o momento de retornar a um conceito, contemporaneamente em desuso na criminologia, de pânico moral, trazido a lume num texto seminal de Stanley Cohen. O que nos parece importante é verificar como o autor desloca alguns sentidos desta noção, se levarmos em consideração as distintas edições da obra.

$\mathrm{Na}$ introdução da terceira edição da obra "Folk Devils and Moral Panics" (COHEN, 2002), o autor afirmará que a retórica do pânico moral dependerá muito menos da quantidade de casos criminais atrelados do que de um giro cognitivo, que pressupõe a pergunta: "como uma coisa dessas foi acontecer justamente aqui?" ou "se aconteceu aqui, poderia ocorrer em qualquer lugar" (COHEN, 2002, p. xii). O pânico moral exige, para a sua criação, de uma teoria causal que lhe dá sustentação (COHEN, 2002), uma linguagem que pode comunicar um evento singular, relacionando-o a outros tantos casos, de modo a dar-lhe um sentido determinado no imaginário popular, ativando, assim, aquele sentimento de pretensão insatisfeita de que falava Laclau.

De fato, uma mudança fundamental que ocorreu na percepção do crime, condicionando, a reboque, a conformação político-imagética do próprio pânico moral é a retórica dos movimentos pró-vítimas: associações de pais contra a violência, movimentos em prol da ampliação da pena para os crimes praticados contra animais, associações de vítimas de abuso sexual, 
etc., todos são exemplos desta ativação de pretensões insatisfeitas, produtos dos pânicos morais que emergem. Como acentuará Cohen (2002, p. xxiv), "mais do que um estímulo (mensagem da mídia) e uma resposta (comportamento da audiência)", a ideia de pânico moral perseguirá os pontos em que os alertas morais são aumentados ou decrescidos.

Além da retórica vitimária, a emergência do risco como uma categoria criminologicamente relevante - especialmente para as posturas gerencialistas - e sua conexão com a segurança pública explica, embora parcialmente, os episódios de pânico moral. O risco é uma categoria central a uma sociedade na qual os papéis sociais, as identidades e subjetividades são definidas a partir de derivações como insegurança, medo e vitimização. Assim, o surgimento de teorias como as de prevenção situacional (que tem seus germens na Escola de Chicago), oportunidade, racionalidade e prevenção acabam sendo importantes instrumentos na deflagração de pontos de emergência de pânicos morais. O elemento fundamental que não pode ser perdido de vista reside na circunstância de que a diminuição do risco e da insegurança, assim como o aumento da segurança, dependerá de zonas de moralidade pública e de sua condensação em plataformas políticocriminais.

Considerando tudo aquilo até aqui exposto, arriscaríamos dizer que o "pânico moral permanente" constitui-se como um oxímoro. Como destacará Cohen (2002), um pânico pressupõe a temporariedade, ele é espasmódico, episódico. Não pode ser permanente.

O que de fato é permanente é o fenômeno do populismo nas democracias ocidentais, como anteriormente retratado. Não podemos ter um "populismo penal permanente" nem tampouco um "pânico moral permanente". Leis que entraram recentemente em vigor no Brasil, como a Lei Maria da Penha, Lei Joana Prado, Lei Carolina Dickmann, além de um projeto de Novo Código Penal, que homenageia duas vítimas, Ives Ota e João Hélio, correspondem muito menos a um "populismo penal" enquanto fenômeno político permanente do que a ativação episódica de pretensões sociais insatisfeitas, manifestadas em toda a sua potencialidade através de singulares momentos de pânico moral. 
O que a doutrina criminológica tem compreendido como "populismo penal" trata-se, a nosso juízo, da captação das pretensões democraticamente insatisfeitas, através da precipitação de fatos singulares, que concorrem cada qual à sua maneira, para produzir alterações no imaginário popular, sobre o sentimento de segurança-insegurança, percepção do risco, da moralidade pública, etc. A ativação destes sentimentos não pode ser feita de maneira industrial ou unilateral, como costumeiramente se acredita. Ela requer a participação de diversos atores. Os pânicos morais podem ser catapultados para a seara do sistema de justiça criminal - e com frequência impressionante tais demandas ali aportam produzindo conteúdos político-criminais. Contudo, a insistência da criminologia "crítica" em denominar o populismo penal como um movimento "ad eternum", arquitetado sob uma plataforma que congloba estruturalismo, interacionismo simbólico e certa dose de cegueira política, não oferece contributo algum. Nem para a discussão político-criminal, quanto menos para a própria criminologia.

\section{CONSIDERAÇÕES FINAIS}

Acreditamos que seja o momento de nos debruçarmos sobre as condições exigidas para que um pânico moral obtenha sucesso, isto é, consiga ativar subjetividades políticas, para além de uma inócua aderência à expressão "populismo penal", cujo emprego, banalizado, indica, a rigor, dois problemas típicos das atuais discussões (criminológicas) sobre o sistema criminal: o primeiro deles diz para com a permanência de uma tradição política autoritária, mesmo em tempos democráticos, fato que é pouco explorado pelo discurso criminológico crítico de orientação marxista; o segundo, por fim, concerne à postura reformista demonstrada - ainda que involuntariamente - por todas aquelas análises que se limitam a afirmar que o problema é apenas o uso populista do sistema de justiça criminal. Neste contexto, escamoteia-se o fato de que o principal problema é o próprio sistema criminal. Uma crítica radical jamais poderá se contentar com a reforma. 


\section{REFERÊNCIAS BIBLIOGRÁFICAS}

AGAMBEN, Giorgio. Meios sem Fim: notas sobre a política. São Paulo: Autêntica, 2015.

ARDITTI, Benjamin. Populism, or, Politics at the Edges of Democracy? In. Contemporary Politics, Vol. 9, Issue 1, 2003.

BARATTA, Alessandro. Criminologia Crítica e Crítica do Direito Penal: introdução à sociologia do direito penal. $3^{a}$ Ed. Rio de Janeiro: Revan: Instituto Carioca de Criminologia, 2002.

BARRACLOUGH, Geoffrey. Introdução à histórica contemporânea. São Paulo: Círculo do Livro S.A., 1964.

BAUMAN, Zygmunt. Vida líquida. Rio de Janeiro: Zahar Editores, 2007. BECKER, Howard. Outsiders: estudos de sociologia do desvio. Rio de Janeiro: Jorge Zahar, 2008.

BOTTOMS, Anthony. The Philosophy and Politics of Punishment and Sentencing. The Politics of Sentencing Reform, Oxford: Clarendon, 1995.

BUTLER, Judith. The Psychic Life of Power: theories in subjection. Stanford: Stanford University Press, 1997.

CANOVAN, Margareth. Populism, New York: Harcourt Brace Jovanovich, 1981. 
. Trust the people! Populism and the two faces of democracy. In: Political Studies - Political Studies Association. Volume 47, Issue 1, March 1999. pp. 2-16.

CASTORIADIS, Cornelius. A Instituição Imaginária da Sociedade. São Paulo: Paz e Terra, 1982.

COHEN, Stanley. Folk Devils and Moral Panics: the creation of mods and rockers. $3^{\text {a }}$ Ed. London: Routledge, 2002.

. Folk Devils and Moral Panics: The creation of the Mods and Rockers. New York: Routledge, 2011.

DIVAN, Gabriel Antinolfi. "Qual nossa única reivindicação?” representatividade e cruzamentos políticos para a construção de uma 'criminologia 2.0'. Revista Panóptica - Direito, Sociedade e Cultura. V. 10, $\mathrm{n}^{\circ} 2,2015$.

DOWNS, Anthony. Uma teoria econômica de democracia. São Paulo: EDUSP, 1999.

ELBERT, Carlos Alberto. O Populismo Penal: Realidade Transitória ou Definitiva? Direito Penal e Política Criminal no Terceiro Milênio: Perspectivas e Tendências [recurso eletrônico] - Congresso Internacional em Direito Penal, $8^{a}$ Congresso Transdisciplinar de Estudos Criminais; org. Fábio Roberto D’Avila. - Porto Alegre: EDIPUCRS, 2011, pp. 58-67.

FERRAJOLI, Luigi. Direito e razão: teoria do garantismo penal. $3^{a}$ Ed. Rev. São Paulo: Editora - Revista dos Tribunais, 2010.

FEYERABEND, Paul. Contra o método. $2^{\text {a }}$ Ed. São Paulo: Editora Unesp, 2011. 
FOUCAULT, Michel. Segurança, Território e população. São Paulo: Martins Fontes, 2008.

Vozes, 2010.

.Vigiar e punir: nascimento da prisão. 38. Ed. Petrópolis, RJ:

FREUD, Sigmund. Psicologia das massas e análise do eu. Porto Alegre, RS: L\&PM, 2014.

GARLAND, David. A cultura do controle: crime e ordem social na sociedade contemporânea. Rio de Janeiro: Revan, 2008.

GAZOTO, Luís Wanderley. Justificativas do Congresso Nacional Brasileiro ao Rigor Penal Legislativo. Tese. Universidade de Brasília, 2010.

GERMANI, Gino. Estructura, composición interna y distribución ecológica de las clases populares, medias y altas (1955). La sociedad en cuestión: antología comentada. $1^{\text {a }}$ Ed. Buenos Aires: Consejo Latinoamericano de Ciencias Sociales - CLACSO, 2010.

GIDDENS, Anthony. Modernity and Self-Identity. Cambrige: Polity, 1991.

GLOECKNER, Ricardo Jacobsen. Risco e processo penal: uma análise a partir dos direitos fundamentais do acusado. JusPodivm, 2009.

GOMES, A. C. O populismo e as Ciências Sociais no Brasil: notas sobre a trajetória de um conceito. In: FERREIRA, J. (org.). In: O populismo e sua história - debate e crítica. Rio de Janeiro: Civilização Brasileira, 2001.

GOMES, Luiz Flávio; ALMEIDA, Débora de Souza de. Populismo penal midiático: caso mensalão, mídia disruptiva e direito penal crítico. São Paulo: Saraiva, 2013. 
GRAMSCI, Antonio. Cadernos do cárcere. Rio de Janeiro: Editora Civilização Brasileira, Vol. 2, 2000.

HARDT, Michel; NEGRI, Antonio. Império. $2^{a}$ Ed. Rio de Janeiro: Editora Record, 2001.

INCISA, Ludovico. Populismo. Dicionário de Política (Org. Norberto Bobbio, Nicola Matteucci e Gianfranco Pasquino - trad. Carmen C, Varriale et al). Brasília: Editora Universidade de Brasília, $1^{\circ}$ ed., Vol. 1, 1998, pp. 980985.

KARAM, Maria Lúcia. A esquerda punitiva. In: Revista discursos sediciosos - crime, direito e sociedade ${ }^{\circ} 1$, ano $1,1^{\circ}$ semestre, Relume-Dumará: Rio de Janeiro, pp. páginas 79-92, 1996.

LACLAU, Ernesto. A Razão Populista. Tradução de Carlos Eugênio Marcondes de Moura. São Paulo: Três Estrelas, 2013.

- Política e Ideologia na Teoria Marxista: Capitalismo, Fascismo e Populismo; 1978.

. MOUFFE, Chantal. Hegemonia e estratégia socialista, São Paulo: Intermeios, 2015.

LARRAURI, Elena. Populismo punitivo... y como resistirlo. Revista de Estudos Criminais, n. 25, p. 9-25. Porto Alegre, 2007.

LEFORT, Claude. Pensando o político: ensaios sobre democracia, revolução e liberdade. Rio de Janeiro: Paz e Terra, 1991.

LE BON, Gustave. The Crowd: A Study of the Popular Mind. New Zeland: The floating press, 2009. 
MARTINS, José de Souza. Linchamento, o lado sombrio da mente conservadora. Tempo Social; Rev. Sociol. USP, S. Paulo, 8(2): pp. 11-26, outubro de 1996.

MARTINS, Rui Cunha. A hora dos cadáveres adiados: Corrupção, Expectativa e Processo Penal. São Paulo: Ed. Atlas, 2013.

MATHIESEN, Thomas. Juicio a la prisión: una evaluación crítica. Buenos Aires: Ediar, 2003.

MENDONÇA, Daniel; PEIXOTO, Léo Rodrigues. Do estruturalismo ao pós-estruturalismo: entre fundamentar e desfundamentar. In. Pósestruturalismo e teoria do discurso: em torno de Ernesto Laclau. $2^{\mathrm{a}} \mathrm{Ed}$. Porto Alegre: EDIPUCRS, 2014.

MOUFFE, Chantal. O regresso do político. Portugal: Gradiva, 1996.

PAIVA, Luiz Guilherme Mendes de. A fábrica de penas: racionalidade legislativa e a lei dos crimes hediondos. Rio de Janeiro: Revan, 2009.

PRAT'T, John. Penal Populism. New York: Routledge, 2007.

RIPOLLÉS, José Luis Díez. La racionalidad de las leyes penales. Madrid: Trotta, 2003.

SALAS, Denis. La Voluntè de Punir: Essai sur le Populisme Pénal. Paris : Hachette, 2005.

SCHUMPETER, Joseph. Capitalismo, Socialismo e Democracia. Rio de Janeiro: Fundo de Cultura, 1961.

SILVA SÁNCHEZ, Jesús-María. La Expansión Del Derecho Penal: aspectos de la política criminal em las sociedades posindustriales. Madrid: Civitas, 2001. 
SIMON, Jonathan. Governing through crime: how the war on crime transformed American democracy and created a culture of fear. Oxford: Oxford University Press, 2007.

SOUZA SANTOS, Boaventura de. Reinventar a Democracia. Portugal: Gradiva, 1998.

SOZZO, Máximo. Populismo penal, Proyecto Normalizador y "prisióndepósito" en Argentina. Sistema Penal \& Violência. v. 1, n. 1, 2009, pp. 3365.

TARDE, Gabriel. A opinião e as massas. $2^{a}$ Ed. São Paulo: Martins Fontes (Col. Tópicos), 2005.

WEFFORT, Francisco Correia. O populismo na política brasileira. Rio de Janeiro: Paz e Terra, 1978.

WITTGENSTEIN, Ludwig. Investigações filosóficas. Petrópolis/RJ: Vozes, 2014.

WORSLEY, Peter. O conceito de populismo. In: TABAK, F. (org.). Ideologias: populismo. Rio de Janeiro: Eldorado, 1973.

YOUNG, Jock. A sociedade excludente: exclusão social, criminalidade e diferença na modernidade recente. Rio de Janeiro: Revan, 2002.

.Voodoo Criminology and the Numbers Game. In: Cultural Criminology Unleashed (2004), org. Ferrell, J., Hayward, K., Morrison, W., and Presdee, M. (eds), Londres: Glass House Press. Disponível "online": http://www.culturalcriminology.org/papers/chap1-jockyoung.pdf.

ŽIŽEK, Slavoj. Em Defesa das Causas Perdidas. São Paulo: Boitempo, 2011. 
DELICTAE, Vol. 2, №3, Jul..-Dez. $2017 \quad 297$ 